Florida International University

FIU Digital Commons

FIU Electronic Theses and Dissertations

University Graduate School

$11-19-1982$

\title{
A study to determine the probable effects casino gambling might have on the Latin American share of the tourist market located in Miami, Florida
}

Francis Joseph Caponio

Florida International University

DOI: $10.25148 /$ etd.FI14052567

Follow this and additional works at: https://digitalcommons.fiu.edu/etd

Part of the Gaming and Casino Operations Management Commons

\section{Recommended Citation}

Caponio, Francis Joseph, "A study to determine the probable effects casino gambling might have on the Latin American share of the tourist market located in Miami, Florida" (1982). FIU Electronic Theses and Dissertations. 2038.

https://digitalcommons.fiu.edu/etd/2038

This work is brought to you for free and open access by the University Graduate School at FIU Digital Commons. It has been accepted for inclusion in FIU Electronic Theses and Dissertations by an authorized administrator of FIU Digital Commons. For more information, please contact dcc@fiu.edu. 
A STUDY TO DETERMINE THE PROBABLE EFFECTS CASINO GAMBLING MIGHT HAVE ON THE LATIN AMERICAN SHARE OF THE TOURIST MARKET LOCATED IN MIAMI, FLORIDA

\author{
A Thesis \\ presented to \\ the Faculty of the School of Hospitality Management \\ Florida International University
}

In Partial Fulfillment of the Requirements for the Degree of Master of Science

by

Francis Joseph Caponio

November, 1982 
To Professors Donald Greenaway and Charles L. Ilvento

This thesis, having been approved with respect to form and mechanical execution, is referred to you for judgment upon its substantial merit.

Dean Anthony G. Marshall

School of Fospitality Management

The thesis of Francis Joseph Caponio is aperoved by:

Professor Donald Greenaway

Professor Charles L. Ilvento

Date of Examination: November 19, 1982 
PREFACE

This paper was undertaken in order to study the effects casino gambling would have on the Latin American share of the Miami tourist market. In order to properly carry out the study, the issue of casino gambling in South Florida had to be discussed. The author discussed the issue with both proponents and opponents of legalized casino gambling in Florida.

In order to determine the Latin American reaction to legalization of casinos, a survey was distributed to Latin American tourists from Columbia, Venezuela and Mexico at the Miami International Airport. The results of the survey provided the author with the data necessary to evaluate the validity of the hypothesis. The author tried to carry out the study in an unbiased, professional manner. The ideas and conclusions stated in this paper are those of the author, unless otherwise noted. 


\section{TABLE OF CONTENTS}

PRELIMINARIES

The Preface

The Table of Contents

The Acknowledgements

The Biography of the Researcher

I. THE PROBLEM AND ITS SETTING

The Statement of the Problem

The Hypothesis

The Limitations

The Definitions of Terms

The Assumptions

The Importance of the Study

II. THE REVIEW OF THE RELATED LITERATURE

Short History of Gambling in the United States

Why People Gamble

Different Forms of Betting

Gambling in Las Vegas, Nevada

Gambling in Atlantic City, New Jersey

The Tourist Industry of Dade County and Miami Beach

The Economic Impact of Legalized Gambling on South

Florida

The Issue of Legalized Casino Gambling in Dade County

The Latin American Tourist

III. THE GENERAI PROCEDURE

The Data and its Collection

Treatment of the Data

IV. A DISCUSSION OF THE EFFECT OF LEGALIZED CASINO GAMBLING ON FLORIDA AND THE LATIN AMERICAN TOURIST

Interview with Chuck Rosen, Louis Fisher and

William Anderson 
V. THE RESULTS

Introduction $\quad 50$

The Total Latin Questionnaire $\quad 51$

$\begin{array}{ll}\text { The Venezuelan Results } & 60\end{array}$

The Colombian Results $\quad 65$

The Mexican Results $\quad 69$

The Hypothesis $\quad 75$

$\begin{array}{ll}\text { Other Findings } & 77\end{array}$

VI. SUMMARY, CONCLUSIONS AND RECOMMENDATIONS

Summary

79

$\begin{array}{lr}\text { Conclusions } & 80\end{array}$

$\begin{array}{lll}\text { VII. BIBLIOGRAPHY vi } & \text { vi }\end{array}$

$\begin{array}{lr}\text { VII. FOOTNOTES } & \text { vii }\end{array}$

IX. APPENDIX A $\quad$ X

X. APPENDIX B $\quad$ xi

XI. APPENDIX C $\quad \therefore \mathrm{XX}$ 


\section{ACKNOWLEDGEMENTS}

The author would like to thank Ileana Loria and Dr. Joseph and Mrs. Virginia Caponio without whose gracious help and support this paper could not have been written. He also extends great thanks to Mr. Chuck Rosen, Mr. Louis Fisher and Mr. William Anderson, Jr. for their unselfish gifts of time and information. 


\section{BIOGRAPHY OF THE RESEARCHER}

Francis Joseph Caponio was born in Washington, D.C. in December of 1957. He graduated Cum Laude from Shenandoah College and Conservatory of Music with a B.S.in Management and a minor in Music.

From 1973 until 1976, he worked in various positions at the Warehouse Restaurant in Alexandria, including short order cook and inventory clerk. During his four years of college, he played in various performing ensembles, including jazz bands and the local Symphony Orchestra.

Upon graduating from college, he went into the Army Reserve as an Intelligence Analyst and also worked at the U.S. Department of State with a consulting firm.

He is currently enrolled in Florida International University Graduate Program in the Hospitality Management School. Upon completion of his Master's degree, Mr. Caponio will be commissioned a 2nd Lt. in the U.S. Army and hopes to enter their club management school. 


\section{THE PROBLEM AND ITS SETTING}

The purpose of this study is to determine what effect legalized casino gambling would have on the Latin American tourist market of Miami.

The Hypothesis:

The hypothesis is that the typical Latin American tourist would consider legalized casino gambling to be a positive inducement to vacation in Miami or return for future visits.

\section{Limitations:}

The study will be limited to identifying and surveying tourists from Venezuela, Colombia and Mexico coming into Miami International Airport.

\section{Definition of Terms:}

Casino gambling-Casino gambling shall include those gaming activities commonly known as baccarat, blackjack or twenty-one, craps, keno, poker, roulette and French roulette, and slot machines and shall include such additional gaming activities as may be permitted by general law. The operation of a lottery or lotteries, other than bingo, shall also be permitted as a casino gaming 
activity; provided, however, by general law, the concurrent or exclusive right to conduct a lottery or lotteries may be reserved to the state.

In addition, to operate as a casino gambling activity, the operation of slot machines upon properties licensed for parimutuel wagering is hereby authorized (See Appendix C).

Latin American Tourist-The Latin American tourist in this study is any person from Colombia, Venezuela on: Mexico who travels 100 miles or more from his area of origin to Miami and/or stays one night in a Miami area hotel, motel, or other transient accommodation facility $\stackrel{1}{?}$

Assumptions:

The first assumption is that a random sampling of Venzuelan, Colombian and Mexican touristes conducted in the Miami International Airport will yield a fair representation of the typical Latin American tourist.

The second assumption is that casino gambling, although not yet legal, has a good chance of authorization through ballot in the general election to be held in November of 1984. This amendment proposes that changes be made in Article $\mathrm{x}$, Section 15 of the Florida Constitution. 
The Importance of the study:

It has long been felt by many that casino gambling might have a very positive economical impact on Miami, Florida. Many studies have been undertaken that attempt to prove this. However, no study has limited its research to determine the effects casino gambling might have on the Latin American tourists who comprise a large portion of the Miami tourist market. Studies have also been undertaken to determine the breakdown of the Latin American tourist market.

To this date, no study has specified the effect that casino gambling might have on the Latin tourist market. Because no: study has dealt with this particular problem, a void in research exists. This study will attempt to fill that void by researching the Venezuelan, Colombian and Mexican sections of the Miami tourist market and predicting their response to legalized casino gambling. These sections of the Latin tourist market were selected because they comprise the greatest portion of the overall Latin market which visits South Florida.

The study will provide information that could be useful to various organizations committed to the legalization of casino gambling in Florida. Through discussions with various directors of these organization, it became clear that the Latin portion of 
the tourist market has not received adequate consideration as a major market for casino gambling. This study will try to show that casino gambling could prove to be a very big tourist draw for the Latin American market and thus provide an additional argument in favor of legalized casino gambling in Florida.

This study will also be of some interest to the Dade County Tourism Department since it will provide information on a little studied aspect of the market.

of course, everything hinges on the legalization of casino gambling and if it never comes to pass, the paper might seem useless. But, as mentioned earlier, the ballot comes up in November of 1984 and thus a study of this nature is important now while it still might have a positive effect on the outcome of legalized casino gambling in Miami, Florida. 


\section{THE REVIEW OF THE RELATED LITERATURE}

Although the major focus of this paper is the effects that casino gambling would have on the Venezuelan, Colombian and Mexican portion of the Latin tourist market in Miami, it is necessary to mention and discuss some of the related topics which are very important to the central issue of this paper. In order to gain a better understanding of the elements which led the way in the drive for legalized casinos in Miami, it would be helpful to understand why people gamble, what the different forms of gambling are, and a little about the history of gambling in America. From there, the history of Southern Florida and Miami Beach as a tourist stop will be examined. The major problems facing the South Florida tourist industry will also be discussed and analyzed.

In the final section of the review of the related literature, the Miami drive for legalization will be analyzed and an overview of the Latin tourist market will be given.

Short History of Gambling in the United States

The United States has been a gambling society since before there was a United States. The Constitutional Army was funded 
by a lottery and state charted lotteries supported all manner of good works until scandals in the 1820's forced the closing of all but the Louisiana state lottery, which drew national action even late in the 19th century. Gambling was part of colonial life. During this time, horse racing was popular with the upper class while craps and poker appealed to the lower class. In the 20th century, laws rendered most of gambling illegal, yet it never really stopped. Organized crime gave gambling the organization it needed to withstand all but the toughest and most honest lawmen and legislators. Organized crime always had the capital to corrupt government, especially at the local level, and it still does. Thus, gambling never really died out, it just went underground.

\section{Why People Gamble}

Today, the general public enjoys gambling of one sort or another; bingo, the weekly office football pool and horse racing are now commonplace. Four powerful forces influence the general public's urge to gamble.2 They include: entertainment, escape, boredom, and change in social attitudes.

Many people gamble simply to have a good time. The entertainment includes the glamour of the surroundings and the thrill 
of the moment before the slot machine displays one cherry, one orange and a bell. As the "ponies" or dogs are coming into the home stretch, who can help but feel an unsettling of the stomach. Lady luck has a special appeal to today's individual. Most people cannot figure out inflation or foreign affairs, they do not know the answer to the crime problems or the adolescent rebellions of their children, so they gamble to see where they stand with fate. As in their lives, they let Lady Luak décide what will happen. This leads to the next force.

Escape is also a powerful factor in the urge to gamble. More Americans have more money now than ever before, but it is worth less. Allowing money to waste away in the bank just does not seem wise. Why not risk the money on the horses or in the slot machine. It seems less irresponsible than it might in a more stable society. When the gambler is at the table, his mind is not concerned with the usual problems. Instead, he only has to think of two thingswin or lose.

Boredom is another major factor which influences gambling. It is harder and harder to find a job that offers challenge and excitement. Television exposes a person to more excitement in a week than his granfather saw: in a decade. A void in "experience" has been created which gambling has filled. 
Finally, social attitudes are rapidly changing. Yesterday's vices are today's interesting experiences, especially if they do not cause harm to anyone. Today's young adults did not grow up in the 30's when the mobs were both feared and known. Therefore, they cannot understand why the Federal or state government cannot ensure the safety of the casino industry since they regulate everything else.

All of these influences have aistrong pull on society to recognize gambling as a somewhat legitimate activity. There are several ways that one can bet money that are legal to a certain extent. These gambling vehicles include: lotteries, parimutuel betting, bingo and casinos. These are the organized activities and do not include the back alley crap games or the Saturday night poker games.

\section{Different Forms of Betting}

Lotteries: For the first time in this century, lotteries became legal in New Hampshire in 1964. This attempt to gain funds for the state marked the turning point for public acceptance of gambling. New York was next to try the state lottery as a means of raising revenue but did not take in nearly as much revenue as it expected, thus, the state lottery was not a big success. But, 
when New Jersey implemented computer based weekly lotteries that cost only 50 cents yet paid out hundreds of thousands in winnings, the action picked up.

One of the main goals of the state lottery was to force illegal operations out of business. The lottery did not prove too successful at this because the local "bookies" extended credit when the state could not. Thus, illegal operations thrived and in a sense, benefitted from the expanded markets that the state lottery created.

Usually, about $40 \%$ of the gross sales from lottery games goes into a state general fund or into a sepcific program. The total state "take" amounts to millions of dollars, yet it does not swell state treasuries. The total "take" usually does not amount to more than 18 or $2 \%$ of the annual state tax collections. But, as state officials are quick to point out, lottery revenues are not taxes and, therefore, cannot be increased by forcing it upon the citizens. " The consumer bets only what he wishes and thus, the lottery is more or less a form of entertainment. Whatever revenue comes in is voluntary and, therefore, the state usually comes out ahead, both in image and revenue. 
Parimutuel betting: It has long been considered a fact that the largest spectator sport in the United States is horse racing. At a ract track, the bettors bet against each other instead of the bookmaker. This is why it is called parimutuel betting. The money is usually divided up in this manner: 82-85\% goes to the winner and the remaining $15-18 \%$ is divided between the track and the state. 5 This is probably the most common form of gambling on a legalized level. Even here, organized crime is said to be in on the action. Since the big winners must pay federal taxes on their collected winnings, gamblers put their bets into the hands of illegal bookmakers who do not report anything and thus do not tax the wins. The "bookies" also extend credit to them; another feature the track cannot offer. Still, the sport provides hours of enjoyment to millions of Americans each year.

Bingo: This game is considered by many to be a game for middle aged and older women which is generally run by a church or social organization for charitable purposes. This form of gambling brings in at least two million dollars a year and thus must be considered more than a casual game. ${ }^{6}$ Again, organized crime is in on the operations.

In many states and counties, the laws that govern bingo are vague and the police often overlook the operations in the 
name of charity. There are many schemes that the criminal can implement to gain money from bingo operations. One method is to under-report income or to "skim" off the top of the "take"; another uses hired help who pocket a percentage of the income and turn it into the "management" at the end of the night. But, Bingo does serve the community by raising money for churches and the community, and therefore, the few "bad" operations should not be allowed to tarnish the image of the good.

Casinos: During modern times, Nevada was the only state in the union which had authorization to allow casinos. Now, Atlantic City, New Jersey is also party to legalized casino gambling. People from around the country and the world flock to Las Vegas and Reno to gamble. There, the days of the big show, the big spender and the city that never sleeps are still alive and well. The casinos offer an assortment of gaming activities which include: black jack, slot machines, keno, roulette, baccarat, poker and a variety of other games. In addition to this, the cities offer a showcase for the stars and a taste of expensive living. All of this adds up to money, lots of money. The casinos offer the best in food, drink and accomodations in order to entice the tourist to gamble. They create an environment that is seldom:. duplicated except in very few places around the world. 7 . This is just a brief 
description of casinos that will be covered in much greater depth later in the paper. Each form of gambling is popular and serves its own select market. Gambling is here to stay. If not legally, controlled by the Federal, State and local governments, it will be illegally controlled by organized crime. The market exists and nothing is going to change that fact.

The commission on the Review of the National Policy toward Gambling acknowledged: "Gambling is inevitable. No matter what is said or done by advocates or opponents of gambling in all its various forms, it is an activity that is practiced or tacitly endorsed, by a substantial majority of Americans." 8

The commission went on to raise a number of issues that it felt bore serious consideration:

-A significant number of Americans think that gambling, in any form, is wrong on both religious and secular grounds. -Government may undermine a basic tenet of our society by encouraging profit through chance rather than work. -Many people believe that state sponsored gambling violates the principle of private enterprise. J-The goals of legalized gambling-revenue rasing and crime control-are incompatible because the legal games may not be able to compete with the illegal ones, which do not pay taxes 
or require bettors to pay taxes.

-Legal gambling is a regressive form of taxation in which the poor pay out a greater share of their earnings than the rich.

-The gambling industry may grow faster than the state's ability to control it.

-The availability of gambling creates new gamblers and may lead to "ungovernable increases in the size of the gambling clientele." 9

These are valid questions that must be answered, yet, the fact remains that gambling is here to stay and to ignore the issue will not lead to any viable answers.

The next section of this pater will focus on two main centers of casino gambling, Las Vega and Atlantic City.

Gambling in Las Vegas

In 1931, the first casino opened legally in Las Vegas. At that time, there were 91,000 people living in the state. Las Vegas had about five blocks of paved streets and the road out of town to Los Angeles was made of dirt. 10

In 1982, Nevada is the nation's fastest growing state with more than 799,000 residents, quite an increase from the 1931 
figure. $\stackrel{11}{.}$ Gambling is the state's largest industry, contributing at least $\$ 100,000,000.00$, nearly half the state's annual tax revenues. There is no state income tax and the sales tax is only $3.5 \%$ on the dollar. $65 \%$ of all the jobs somehow depend on the gambling industry. In Las Vegas, the median family income is $\$ 21,000.00$, placing it among the nation's top $10 \% .12$ The tourist industry is healthy and strong. The city has come to be known as the entertainment capital of the world. Jerry Lewis, Frank Sinatra, Wayne Newton and Diana Ross are just a few of the big names that play to the tourists in this city. The city has the most extensive convention facilities of any place: 48 major hotels with almost 48,000 rooms. In 1981, more than 600,000 convention delegates dropped $\$ 227,000,000.00$. This is no small feat in these economically troubled times. 13 Harry Reid, chairman of the Nevada Gambling Control Commission, stated that "Las Vegas is just a big hunk of desert. It is the seventh largest state in landmass, but only on a small part of that will a blade of grass grown. People come here, and what they spend comes from someplace else. It is not made on the tables." 14

Yet, Nevada, and especially Las Vegas, have problems. Despite all of their efforts, Las Vegas gaming officials have 
not been able to rid the city of its ties with organized crime. Gaming revenues have declined as a result of the nation's economic problems. Soaring airline ticket prices and the rise in the price of gasoline have proved to be major factors in this decline. The legalization of gambling in New Jersey's Atlantic City has also added a competitive factor to the industry. Yet, Las Vegas survives and should continue to do so. The city was founded on gambling and now depends on it for its life blood. Despite the few negative aspects, Las Vegas has a high standard of living and the tourist industry is in good shape. Other resort cities like Miami Beach are not. Atlantic City was not in very good shape either until legalized gambling turned it around by generating investments in new hotels and thus capturing a new tourist market.

Gambling in Atlantic City, New Jersey

Casinos opened their doors in Atlantic City, New Jersey in May of 1978. Casinos were legalized in hopes that this ailing resort would again flourish with business. The gaming has done much to re-invigorate Atlantic City's economy. Casinos have invested more than $\$ 1,000,000,000.00$ so far, creating more than 23,000 jobs. Legalization has resulted in the 
building of many new, large hotels and a significant rise in the value of real estate. "Federal, state and local tax revenues have soared, with an average of $\$ 700,000,000.00$ pouring in from each casino." 15 ?et, the city is far from complete in terms of housing the tourist.

Atlantic City needs 10,000 hotel room to attract major conventions and direct airline service. 16 with the nine hotel-casinos operating today, the city still needs at least another half-dozen hotels and another $\$ 1,000,000,000.00$ before its dream of wealth comes true. Yet, it is in much better shape now than it was before casinos were legalized. A major question remains-can New Jersey make the city more attractive to investors but still keep control tight enough to prevent penetration by organized crime?

New Jersey has long had a record of corruption in government and ties to organized crime. In order to ensure its people that organized crime would not own the casinos, the state government had to implement strong controls and regulation In fact, it is said that the gambling industry in Atlantic City is the "world's most tightly regulated business." 17

State rules dictate who can operate, who can work in and who can sell good or srvices to a casino. It specifies to managemen 
how many employees must be on the casino floor at a given time. The state also forces the casinos to provide plenty of entertainment for the gambler and even sets hours. Each casino must operate a large security force that ensures both employee and gambler honesty.

To ensure that all rules are followed, thirty state inspectors work right on the premises at each casino. Twice a day they help casino employees gather and count the winnings... Thus, Las Vegas has eliminated perhaps the most serious problem: that still plaques the casinos, "skimming" or taking cash off the top of the winnings.

Each company buying a license to open a casino must pay for a rigorous investigation of itself and its top officials by the New Jersey Gaming Commission. The bottom line-"state officials feel confident that the companies running casinos in Atlantic City are not controlled by the underworld. "19

In New Jersey, the state adequately controls casino gambling. The state of Florida could implement the same procedure to safeguard its casinos. Atlantic City was a dying resort town, now it is alive. Miami is a dying resort town, now it is....? 


\section{THE TOURIST INDUSTRY OF SOUTH MIAMI AND MIAMI BEACH}

"Southern Florida's Gold Coast, a thin strip of sundrenched sand and aging hotels that stretches north from Miami Beach, has fallen on bad times. The beaches have been slipping into the Atlantic and the tourist are slipping north:-to:Disney World and south to Caribbean casinos." 20 This was the first sentence in an article which appeared in Time magazine on September 18, 1978 entitled "Gold Coast Gambling". Even though it was written three years ago, it still is accurate today, maybe even more so. The trouble the tourist industry faces today is serious and unless something is done soon, the problem might prove even more difficult to solve. Let us start at the beginning.

Miami Beach started 60 years ago by the efforts of one investor, John Collins. After a series of failures with a coconut plantation and grapefruit and avocado groves, he turned his attention to a resort that was to become the "fun and sun capital of the world". The area continued to grow through the 1950's, 1960's and 1970's. The population tripled, real estate markets boomed and the tourist industry grew. 
At first, the volume of tourists was relatively small, but highly affluent. With the advent of air travel, the tourist number started to grow. At the same time, the pleasantness of the winter climate led may tourists to buy real estate in South Florida and to build winter homes. Of course, once they took up permanent residence, they failed to support the tourist industry as before.

After World War II, tourism continued to expand at a much greater pace. This is when the trouble started, as Professor Luytjes notes:

Facilities were expanded on Miami Beach, but unfortunately older facilities were not replaced as they became obsolete. The thrifty tourist was sought. Also, a-number of hotels started to accomodate the elderly who wanted to remain In Miami Beach permanently. While Miami Beach never had catered to the young per se, the build-up of elderly residents started to give Miami Beach a particular image. This is not to say that no attempts had been made to cater to younger tourists as well as to attracting the family tourist, but success has been limited and the erosion of the beach has not been helpful in these attempts either. 21 
Another factor that points out Miami as a "resting place" for the old is the fact that "almost half of Florida's average yearly gain of 220,000 people comes from those aged 65 or older." 22

The picture here is clear. Miami is quickly turning:into a bedroom city. A drive down Collins Avenue will visually confirm the fact that most of the residents and visitors are in the latter stages of life. This image makes it difficult to attract the young adult market which should be an important target for the city's current marketing efforts.

Probably, the most negative image of Miami that has arisen in recent years is the deterioration of the physical facilities. as well as in the services rendered. The main cause of this is the fact that the hospitality facilities are not running full swing year round. Instead, they do a moderately successful business during the season, but when it ends, so do the profits. This all boils down to an average annual occupancy level for Miami Beach hotels of less than $70 \%$.

This is a trend that any hospitality employee can explain. In Southern Miami, the major tourist season runs from late November through March and then declines to hit bottom in the summer months of July and August. This is contrary to the other general resort areas which receive their greatest tourist flows 
in the summer months when families usually vacation because the kids are out of school and the head of the household is taking a much deserved break from work.

Because of this, it is becoming extremely difficult to entice investors to make multimillion dollar investments in new hotels and facilities. Without new hotels and renovation of the old hotels, Miami really has nothing new to offer. Yet, the need for new hotels exists, especially if Miami hopes to draw in convention business which used to be a large portion of the Miami market.

Another major problem which has arisen for the Miami tourist market is Disney World, At one time, Miami Beach was the primary Florida resort. But, ever since-Disney World opened up, Miami has had to take a back seat. "Disney World has been the tourist miracle of the century. It has been a booming success since its opening day. ${ }^{23}$ Disney World has spawned countless new modern and competitive hotels. Even more important to this paper is the fact that the Latin American visitor is being channeled directly to Disney World and away from South Florida.

It seems that Northern Florida has more big attractions to offer than South Florida. "Three major Florida tourist 
attractions, Walt Disney World, Busch Gardens and cypress Gardens are pushing toward record years while South Florida tourist attractions are fighting to break even." 24

The fact is clear. The Miami tourism industry is in bad shape and will continue to deteriorate unless something is done. Casino gambling might prove to be the answer.

\section{THE ECONOMIC IMPACT OF CASINO GAMBLING ON SOUTH FLORIDA}

In September, Frank Castaneda and Professor Jan B. Luytjes of Florida International University's School of Business and Organization Sciences released a paper titled The Economic Impact of Legalized Gambling on Southern Florida. This paper studies many significant topics relevant to this paper. Miami has seen a broad decline in the viability of its economy. At first, this was attributed to the woes of the national economy, which was true to some extent. When the national economy started its recovery and the Dade County economy did not follow suit, other factors became evident. In reality, a general structural change has taken place in the Southern Dade economy which has had a negative effect on some areas of the economy while a positive effect on others. These factors include the following: 
1. A diminishing economic significance of tourism. The impact of the developments in Central Florida are beginning to be felt.

2. The average real income of the retiree coming to Dade County is less, while the real income of the retiree presently living in the area is diminishing as a result of inflation. The economic consequences are significant, particularly in terms of social overhead costs that must be carried by the community as it expands.

3. The large influx of Cuban-Americans, as well as other Latin Americans, into the area has changed the demographic aspects of the community and will have subsequent consequences for future population shifts.

4. The growing international image of Miami has been attributed to expanded economic activities in such areas as trade, foreign tourism, international banking, and the location of administrative headquarters for organizations engaged in international activity.

5. The development of a metropolitan area with all the characteristics associated with it. - The increase in the size of the market has allowed for some import-substi-. tution expansion in the manufacturing sector. 26

As can be seen from the factors listed, the last two things should prove a positive economic factor if utilized effectively.

Probably the worst outlook is for the Miami tourist industry, particularly Miami Beach, which exists mainly on the flow of tourist dollars. Again, Professor Luytjes' study has found some relevant factors which have led to the bleak economic picture of the tourist sector of the economy. These include : 
1. The deterioration of physical tourist facilities. as well as a deterioation of services.

2. The impact of the development of the tourist industry in Central Florida, particularly with respect to the car-traveling tourist.

3. The absence of the development of many new attractions in South Florida.

4. The increase in population of South Florida has started to encroach upon the tourist space requirement. Recreation facilities, as well as beaches, are utilized by local residents in increasing numbers.

5. The deterioration of the beach has diminished the competitive position of Miami Beach.

6. The increased amount of local elderly residents on Miami Beach has resulted in an image not congruent with effective tourist promotion.

7. The increased number of local residents has created problems not to the benefit of the tourist industry. 26

On the other side of the coin are three positive areas of growth which could prove profitable to the tourist industry in Dade County:

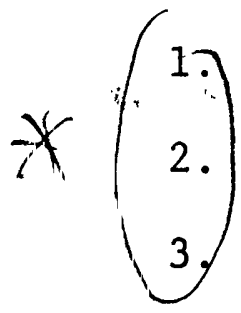

An expansion in the cruise ship business.

An increase in the number of foreign tourists.

An expansion in convention business. It was assumed that the degree of expansion is directly related to the establishment of legalized gambling on Miami Beach.

Factors 2 and 3 are significant factors for this paper

because it draws on one of the major aspects of the study.

The author believes that an increase in the number of foreign 
tourists, particularly the Latin tourist from Venezuela, Colombia and Mexico is very plausible. They could be drawn in greater number, and with more frequency, if casinos were legal.

Now that a brief history of the tourism industry in Miami has been discussed, it is important to see where the industry is in 1982. The Dade County Travel Trend Annual Report released in March of 1982 gives documented evidence " to many of the factors affecting the economy mentioned previously. This study will now be analzyed.

The report states that tourism has long been regarded as the mainstay of the Greater Miami economy. Thus, it. demands special care and consideration so as to ensure its continued development and growth. The report gives evidence that this care and consideration is not evident in the most recent period.

Domestic tourist arrivals to the Greater Miami area experienced one of the worst seasons in recent years by declining 8.97 percent over the 1980 annuals levels. This trend, which began early in the calendar year and which had not changed by the end of December, was present in statistics for both domestic air and auto arrivals. While an encouraging trend has been evident in a comparison of the respective quarterly reports, the inability of the industry to 
provide a positive growth trend during 1981 is evidence of the severe problems inherent, not only in the local economic base but also in national economic patterns. ${ }^{28}$

As was mentioned in the report, international:tourism should be on the rise. It was to some extent in 1982, but not to the degree that it could have been. In fact, if it had not been for the strength of the international market, the overall tourist industry would have been in much more serious shape. The report details this fact:

While problems have continued to exist in the domestic tourism sector, the Greater Miami tourism Industry continues to benefit from a relatively strong international market. While growth did not occur at 1980 levels, positive developments were reported in each of the four market regions with an overall increase of 10.60 percent recorded. This positive increase acted as a moderating influence on the domestic decline, thereby resulting in a more modest 5.35 percent decline in overall total tourist arrivals for the 1981 calendar year. ${ }^{29}$

To some degree, the overall South Miami economy depends on tourism. Fluctuations in the strength and growth of that industry can be felt throughout the local economy. Just how much influence the industry has is a major aspect of the 


\section{Dade County Travels Trends Annual Report.}

In terms of economic impact, the tourism industry retained its position as Dade County's singularly most important industry during 1981. During this past year, tourists contributed a total of 7.28 billion dollars to the local economic base. Of this total, domestic tourists accounted for the largest portion of this income ( 4.79 billion dollars) while the international visitors provided the difference (2.59 billion dollars). It is extremely interesting to note that while international tourist arrivals accounted for a relatively small percentage of the total visitor market, they produced a significantly greater proportional share of the county's tourism income. This trend is expected to continue as the international market continues to mature and develop. Finally, in terms of employment, the tourism industry also continues to maintain its position as Dade County's major employment source, providing an estimated 28.0 percent of the area's total employment. 30

In conclusion, the Miami/Miami Beach tourist industry is in trouble. If drastic action is not taken quickly to reverse the noted trends, the Southern Florida economy will fall off to an even greater degree. Casino gambling offers one solution to the problem. 


\section{THE ISSUE OF LEGALIZED CASINO GAMBLING IN DADE COUNTY}

The debate over the legalization of casino gambling has been raging in Florida for at least five years. Pro and anti-casino forces waged a battle of words fought with millions of dollars. Those who favor legalized casinos say it will bolster a sagging tourist market and enhance state and local revenues. Those who oppose it say it will open the door to organized crime that will prove impossible to shut. No matter which side a person takes, the ultimate benefits and disadvantages are hard to measure.

In 1978 a pro-casino group, "Let's Help Florida", commissioned Economics Research Associates, Inc. to undertake a study of the positive aspects of casino gambling. Going on the assumption that seven casino hotels would be in operation by 1985 , this study predicted that:

(1.) Florida will get $\$ 66,500,000.00$ a year in new sales tax and gaming revenues. Law enforcement and education will benefit from a $6 \%$ tax on gross earnings of casinos. By 1995, the state should be earning $\$ 120,000,000.00$ annually in sales and gaming taxes from revenues of the casinos, which by then should number 15 .

Legalization will lead to construction of eight new luxury hotels along the oceonfront which, along with the renovation of other not so dazzling hostelries, will amount to a new hotel/motel investment along the Gold Coast of roughly $\$ 312,000,000.00$. 
3. Jobs in the South Florida tourist industry will jump from about 20,00 workers to 45,000 workers by 1985 and may be up to 88,000 by 1995 .

4. Numbers of tourists will increase too, climbing to 10.2 million by 1985 and 19.4 million by 1995 . Right now, Miami Beach estimates it attracts 3.5 million visitors annually.

After publicizing these results, the pro-casino group was able to get the question on the statewide ballot in 1978, but with a margin of defeat of 3 to 1 .

There are several reasons why the bill was defeated; one of which being the then state governor, Reubin Askew's stanch opposition to casino gambling. Four years ago, the strongest support for casinos was in South Florida.: Yet, when ballots were tabulated; the question lost in every one of the state's 67 counties. The opponents felt that casions would stop new banking and industry from coming to South Florida because they do not like the kind of environment gambling breeds. They also feared that gambling would stifle the surging economic development in and around Biscayne Bay. These were the ideas which the group "No Casinos" brought up in 1978, but it still uses them today. Louis Fisher, who is the executive director of the anti-casino forces, believes that the same arguments are relevent today. 
Director of the pro-casino forces, Chuck Rosen, counters with this argument; casinos will "give us in Florida something to really talk about, other than our weather and fine beaches. It will bring back to us the big shows that made this area famous and it will trigger construction of luxurious new hotels and restaurants." 32 It also will double the revenues the state receives from tourists.

This year, Mr. Rosen's group is called "Citizens for Less Taxes". The group launched a petition drive to place a state constitutional amendment before the voters in the November 2 election that would not only permit casinos throughout Florida, but also a state lottery and legalization of slot machines at the state's horse and dog tracks and at Jai Alai frontons.

On Friday, July 23, Mr. Rosen made this announcement which ended his group's petition drive to force a statewide referendum on the issue on November 2:

1. The group could collect the 298,743 signatures it needs by August 4 to get its proposal on the ballot, but would lack the 50,000 name cushion it wanted to offset signatures ruled invalid.

2. Once on the ballot, the group could convince a majority of Florida voters to support casino gambling. But, the committee would have to struggle in a confusing mess of state and county elections and also against leading Democratic and Republican gubernatorial candidates, both of whom oppose casinos. 
This announcement followed the release of a telephone survey by M.G.T. of America which asked 676 Floridians:

"Would you favor or oppose legal casino gambling in Florida?" Opponents outnumbered proponents $58 \%$ to $37 \% .34$

Even though the 1982 drive was off, Rosen stated, "We are not gamblers, we're in the tourist business. We want to use casino gambling to'fill hotels and motels. We'11 be in touch with our people. We'll be doing an educational campaign and we'11 send every one of them four or five blank petition forms and ask them to get their friends to sign; that way, we'11 multiply our support." 35

He wants to be ready in the 1984 presidential election. With 600,000 to 700,000 petitions, he feels he can get the issue on the state ballot and passed into law.

\section{THE LATIN AMERICAN TOURIST}

The Latin American market could prove to be the solution to the off-season hotel/motel occupancy lag in Miami. There are several factors which indicate that this might be possible. Miami is, for all practical purposes, bilingual and is becoming increasingly international in flavor and composition.. Thus, Miami offers a unique package among American cities. 
The advantages that Professor Jan B. Luytjes notes include :

1. The weather is similar to that of many Latin American countries.

2. Language difficulties do not exist for the majority of Latin American visitors, since Miami is bilingual in Spanish/English.

3. Its present growth in international banking as well as growth in international business and pleasure.

4. The existence of large commercial centers, where innumerable American goods may be brought at prices lower than those charged for the same goods in Latin American.

5. The similarity between activities in Miami's Latin community and those in the tourist's own country.

6. Its proximity to many Latin American countries. 36 Another strong factor that has become apparent in recent years is that Miami is the main entry port to the Americas: Of the twelve top tourist-producing countries to the United States, four of them, Venezuela, Colombia, Brazil and Argentina al1 use Miami as the primary port of entry.

Miami should still prove to be an important entry port, yet, there are doubts as to Miami's ability to entice and keep the Latin Market, as Professor Luytjes points out: In the Latin hotels, "There were significantly more revenues from foreign markets during the summer (41.7\%) than during the winter $(20.7 \%)$. However, unlike the other two hotel 
categories (convention and other) there was a big difference

in the percent of revenue generated as compared to the percent of registratons $(45.78$ and 31.98 for the summer and winter, respectively). Thus, foreign guests accounted for a smaller proportion of the room revenues in relationship to the proportion of total registrations. This difference is due to either a relatively shorter average stay, fewer guests per registration, or lower priced facilities. ${ }^{37}$

The professor also feels that it is very important to recognize several things about the Latin American tourist:

1. They contribute much more heavily to the retail industry of the community than to the tourist industry and then their impact is limited mainly to specific hotels which cater to, this market.

2. Like any other segment, they cannot be taken for granted. Places such as Disney World are competing seriously for this market and have made deep inroads.

3. This market is extremely fragile, depending strongly on the economic conditions throughout each individual country. Already, Brazil has taken steps to curtail tourism. 38

It is clear that the Latin tourist spends large amounts of money outside of the tourist market. The Latin tourist still comprised an important section of the Miami tourist market, especially in the off-season. It is important to remember that the Latin tourist, like the American, enjoys 
gambling. If casinos were legal in Miami, the Latin tourist flow would probably increase as would the amounts spent on the tourist industry. Up to this point, no one has determined if casino gambling would positively affect the Latin tourist flow to Miami. The balance of this paper will address that issue. 


\section{GENERAL PROCEDURE}

The Data and Its Collection

Most of the data that was utilized in this study was collected through personal contact between the author and the experts and between the author and the Latin American tourists who made up the Latin sample population. The experts who were interviewed, include William Anderson, Jr., Director of the Research Division of the Metro Dade Tourism Department, Chuck Rosen, Chairman of "Citizens For Less Taxes" and Louis Fisher of People Against Casinos. The interviews were conducted at each of the experts' offices.

The survey data was collected from Colombian, Venezuelan and Mexican tourists at the Miami International Airport.

It took a total of 36 hours at the airport in order to compile 93 valid surveys. This data was the most important to the study and proved to be the most difficult to collect.

The results of the survey were tabulated and presented in percentages. First, the responses for the total sample population were broken down. The total breakdown was followed 
by a response breakdown for each group, i.e. the Colombians, Venezuelans and Mexicans.

\section{THE TREATMENT OF THE DATA}

How the Data Was Screened

The completed questionnaires returned by the entire group were screened to eliminate those where the responder failed to meet the criteria of: 1. Colombian, Venezuelan or Mexican nationality.

2. Fill out the required questions of the survey.

How the Data Was Analyzed

The Latin Tourist group response data was analyzed to determine the various possible responses. These responses were manually figured and compiled. These percentages were stated and used to predict the probable response of the overall Latin tourist market.

The questionnaire determined what percentage of the Latin tourist population sampled favors legalized casino gambling. The questionnaire also attempts to find out what the typical economic status is and how much is usually spent 
on a visit to Miami. The survey assessed if gambling would bring the Latin tourist back more often and how much money he would spend in the casinos. The last question asked for the tourist's suggestions as to what would make is stay more pleasurable. 


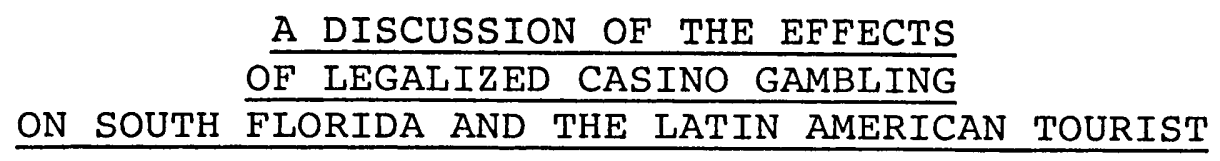

In this portion of the study, the author interviewed three experts on the subject of casino gambling in South Florida and synthesized the interviews into a balanced discussion of the issue. Although the most important aspect of this paper is the projected impact casino... gambling would have on the Latin segment of the tourist market, it is important to remember that casino gambling is not yet legal and the probability of that occurring is far from certain. Thus, it is important to examine the factors which make the casino issue so controversial to the people of South Florida. The discussion will begin by examining the arguments of the proponents of casino gambling.

Mr. Chuck Rosen is the vice president of the Castaway's Beach Club. He is also the Chairman of the "Committee For Less Taxes" which believes that casino gambling would prove to be an economic boon to the Florida economy. With the advent of casinos, South Florida would witness a tremendous 
increase in the tourist flow. This would accompany a rapid expansion in hotel and casino construction. The number of construction and tourist industry related jobs would quickly multiply. State tax coffers would swell through taxed casino wins, lottery revenues, property taxes and the increase in the volume of the other hospitality taxes such as the hotel room tax. The new economy would be able to draw on a very broad tax base and ultimately, the citizen would see his tax situation improve.

Mr. Rosen points to New Jersey as a good example of what casinos can do for a slow economy. He feels Miami would see similar results should Florida legalize casino gambling. In 1975, Atlantic City, New Jersey was experiencing severe economic troubles. Although the city depended on tourism for the vitality of its economy, tourist flow was running about one million persons per year. In 1982, due to casino gambling, the tourist flow in Atlantic City is now between 18 and 20 million a year. This amounts to an increase of staggering proportion.

In 1975, the tourist industry of Atlantic City employed approximately 1,100 persons. Today, in 1982, the hospitality industry accounts for 28,000 jobs. Finally, the total payroll of the tourist industry increased from an approximate total 
of 14.9 million in 1975 to an approximate total of 390 million in 1982 .

These figures graphically present the kind of improvement that casinos can bring about in the tourist industry. Atlantic City is now thriving due to the advent of casinos. Can legalized casinos do the same for the Miami tourist industry?

The State of Florida, through assessments made by the Division of Tourism, received revenue in 1981 of approximately 800 million dollars in tax monies from pure tourism. This came from cigarette, liquor, gas and sales tax. The committee feels that if it were successful in changing the law so that lottery and casino gambling becomes a reality, it would prove to be a tremendous catalyst for the revival of tourism in the state of Florida.

It is projected that within a period of three to five years, an additional 30 to 40 million people would visit the state of Florida. The dollars spent by these additional tourists would create additional tax revenue for the state of Florida. Since inflation and the fact that the sales tax has increased from $4 \xi$ to $5 \xi$, there is no doubt that an increase in tourism to this extent would almost double the income of taxable revenues to the state. This would create 
a projected income of approximately $\$ 1,500,000,000.00 \%$ If we add to this a projected return of approximately 250 million dollars on the statewide lottery and the lesser return of approximatley 100 million dollars from the percentage of gambling receipts to the state, we are looking at a return of revenue dollars to the state of Florida of close to $\$ 2,000,000,000.00$ per year. To this amount, add the increased statewide employment of approximately 50,000 people throughout the tourism industry plus the salaries that would be generated to these employees. The ripple effect of the monies spent by these employees and their families would again generate many many millions of dollars in additional revenues.

The "Committee For Less Taxes" believes that casino gambling would have a pyramid effect on the economy in South Florida. Mr. Rosen pointed out that at one time. Miami Beach was a "big show" town, graced with celebrities such as Frank Sinatra, Sammy Davis, Jr., and Jackie Gleason. This is not the case in 1982. Mr. Rosen says that Miami could adopt a license requirement similar to the one now in effect in Atlantic City which requires live entertainment every night in casinos. Miami might regain its reputation for fine entertainment. 
Mr. Rosen is quick to point out that gambling might also reverse the decrease in convention business that Miami is experiencing. Cities like Dallas, Houston and Pheonix are proving to be very stiff competition for convention business. Each offers a warm climate and many new convention centers to attract the corporate convention planners. Las Vegas has also been a more frequented convention stop as of late. Yet, with casinos, Miami would have everything these centers offer and more. Casinos would give Miami the means to upgrade the other attractions, while also providing a new convention experience.

Mr. Rosen expressed strong interest in the little studied Latin tourist market. Again, he felt that càsino gambling could provide many benefits to the Miami economy through the Latin market. After reviewing the results of the survey (see Appendix A), Mr. Rosen noted that the Latin market was not given the consideration and respect that was due to such an important segment of the overall tourist market. The most important thing that could be accomplished through the legalization of casinos, with respect to the Latin market, was that South Florida's seasonal tourist flow could become year round. If the Latin market increased 
significantly through the benefit of casino gambling and its effects, South Florida could experience a year-round season. The domestic tourist would come in the winter, while the Latin tourist would come in the summer. A year-round season would ensure the strength of the Miami tourist industry by eliminating the start up and slow down periods that now plague the industry. It would be a dramatic improvement for the whole economy.

Miami has long been the Gateway to Latin America, but although the Latin tourist enters the country here, places like Disney World are increasingly becoming their ultimate destination. This is proving a dangerous trend, leaving Miami only with a small amount of the enormous amount of tourist dollars. The Latins have traditionally provided substantial support to various retailers in South Florida. As the length of the stay for the average tourist decreases, so will the amount of money spent on shopping in South Florida. The Latin market is tired of staying in old hotels and eating only average food. They feel that the beaches are dirty, there are too few attractions and there is too much crime. The Latin tourist is becoming increasingly bored with Miami. They want to see new hotels, restaurants and 
attractions. If casino gambling does not come to the rescue, what will? Mr. Rosen feels that casinos could provide all this and more. Why are they not here?

When the author first started this paper, it appeared that the casino gambling issue would go to the polls in the general election on November 2, 1982. This did not materialize. Mr. Rosen noted that the petition gathering drive got off to a late start due to technical difficulties in the legal wording of the petition. These difficulties resulted in a loss of four valuable months in the petition drive. When the drive finally got started on May 15, 1982, it met with little resistance and the required number of 300,000 petitions were almost collected. With the entire Florida legislature running, the "Citizens For Less Taxes committee felt that the movement could well become a political football. Mr. Rosen states that this year's drive was not in vain.: With the efforts of thousands of Floridians gathering hundreds of thousands of petitions, they now have a mailing list that will prove very effective in mounting a successful petition drive as the 1984 general election draws near. With all of the aforementioned benefits, why has the casino bill not been passed? Mr. Louis Fisher is the president 
of Fisher Associates and one of the founders of "People Against Casinos". He is more than happy to answer that question. Mr. "Fisher believes that in the short term, almost everything Mr. Rosen predicts could come true. But, that is only in the short term. The main reason that casinos have not become legal is because the majority of the citizens of Florida do not want them here.'

Florida is located on the tip of the "Bible belt." Many religious citizens feel morally obligated to oppose gambling. The Bible states that it is wrong and that is enough reason for them to vote against it. The religious leaders will always be able to use this argument to defeat the issue because it runs against the belief of the Moral Majority. Mr. Fisher believes that this is the main reason for the failure of the repeated attempts to legalize casinos.

Many Florida business concerns have also organized to oppose legalized casino gambling for several reasons. The major reason is that a "casino image" would adversely affect the thriving financial community that has started to grow in South Florida.

Corporations such as Burger King have located their corporate headquarters in South Florida. If casinos came, 
this could stop. Casinos are traditionally associated-with organized crime. Mr. Fisher asks, "Would you want your corporate or financial headquarters to be located in a city noted for casinos?" This could tarnish a corporation's image. If cas,inos were legalized, many corporations would move out.: It is in this respect that business has and will continue to support the anticasino drive.

Crime is another issue that looms large in the casino issue. Although Mr. Rosen feels that the dramatic increase. in jobs will put the poor to work and thus reduce street crime, Mr. Fisher disagrees. He says that not only will there be an increase in the petty crime element that seems to follow casinos, but that organized crime would come into South Florida in full swing. Mr. Rosen counters that with adequate legislation and control, the organized crime element could be kept out of the casinos much as they are in Atlantic City. Mr. Fisher does not feel that organized crime could be kept out of the casinos and that crime in general would. increase dramatically.

Miami already has a problem with crime. The drug wars that take place between the Cubans and Colombian drug dealers are infamous. Some people call Miami the "Murder Capital 
of the Country." The special task force that was set up by Vice President George Bush to fight drug related cimes ; :

has been very effective. Yet, it has not stopped crime to the extent necessary. Casinos could mean more or less crime depending on what is done. Yet, the question may never be answered. One thing is for sure, the crime issue will always be a major concern of the anti-casino forces.

Mr. Fisher acknowledged that the tourist industry is in serious trouble, yet, he does not feel that the community should rely on something like gambling to expand the economy. Redevelopment is the answer to the problem. Steve Muss has started a redevelopment program for the South Miami Beach area. If this program proves successful and profitable, it may well continue right up the coast. This would give the industry the new hotels and facilities that are so badly needed. He feels that Miami needs to create a current, up to dațe tourist environment if tourism is to thrive again. The largest percentağe of funds for this redevelopment will have to come from private sources, which in today's economy are reluctant to invest in a project unless the final outcome is reasonably assured. The outcome in Miami's case cannot easily be predicted and thus, one wonders if redevelopment can occur on it own. 
Morally, economically and crime-wise, casino gambling is wrong for South Florida. These are the reasons Mr. Fisher gives for the continued failure of the legalization efforts. He feels the same thing will happen in 1984.

It is interesting to note that although not too knowledgeable of the Latin tourist market, Mr. Fisher felt that the results of the survey were accurate. After all, many people t.

like to gamble, especially the Latins, but they do not want to gamble in their own country. Why should the Latin tourist not want to see gambling in Miami? It would prove another attraction. But, he warned, the positive effects that casino gambling might have on the Latin tourist market in Florida will probably never be felt.

William Anderson of the Miami Department of Tourism was interviewed, but because of deparmental policy, was not at liberty to express his feelings. The Tourist Department takes a neutral stance on the casino issue. Mr. Anderson was of great help in comparing the results of this paper's survey with the one completed for his department. This will be discussed in the next section of this paper. 


\section{THE RESULTS}

Thy is the heart of this thesis. In this section, the results of the survey will be given. This will be followed by a discussion of the results of the survey. The evaluation of the data obtained through this survey is solely that of the author and should not be confused with the opinions of the experts set forth earlier in this paper.

As mentioned earlier, the completed survey is made up of 93 valid questionnaires. This number was determined through the use of the Sampling of Attributes Procedure which is used to accurately predict the responses of the total population to within \pm 10 percentage points. (See Appendix C)

During an interview with William Anderson, Jr., Director of the Research Division of the Metro-Dade Tourism Department, the percentage results of this paper's survey were compared to the percentage results of a $\$ 35,000.00$ survey commissioned by the Metro-Dade Tourism Division. The comparison revealed that for questions which could be compared, such as tourist income bracket and average length of stay, this survey's 
results were almost exactly the same as those compiled by the Department of Tourism. This held true for each of the groups surveyed, i.e. the Colombians, the Venezuelans, and the Mexicans. The author believes that this lends more credibility to the validity of the results which will no be discussed.

\section{THE TOTAL LATIN QUESTIONNAIRE RESULTS}

1. What nationality are you?
a. Colombian
$33.33 \%$
b. Venezuelan
$\frac{39.43}{19.24}$
c. Mexican
$\underline{17.24} \%$

In 1981, the largest Latin markets were the Venezuelan $(276,316)$, the Colombian $(188,645)$ and the Mexican $(168,459)$. The entire Latin market totaled 1,088,144 in 1981. The Venezuelans accounted for $25.39 \%$ of the total Latin tourist market. The Colombians accounted for $17.56 \%$ of the total market and the Mexicans accounted for 15.48\%. In this survey, through random selection, the Venezuelans accounted for $49.43 \%$ of the total survey, the Colombian component $33.33 \%$, while the Mexicans accounted for $17.24 \%$

2. What is the main purpose of your visit? 

a. Pleasure
$\frac{57.468}{23 \%}$
d. Pleasure \& business
$2.3 \%$
b. Business
$\underline{2.3} \%$
e. Pleasure \& shopping
$2.3 \%$
c. .. Shopping
f. All of the above
12.648

Pleasure is by far the most common purpose of the Latin tourist's visit. Business and shopping follow with $23 \%$ and 2.3.8 respectively. $12.64 \%$ of the total group comes here for all of the above mentioned purposes. Pleasure and business, and pleasure and shopping account for 2.38 each.

Since pleasure is by far the most common reason for the Latin tourist to visit Miami, it stands to reason that the beaches and attractions, such as the zoo, the Wax Museum, and. Seaquarium are vital resources for bringing the tourist here. Without new attractions and clean modern hotels, how can Miami hope to continue to be a pleasure stop?

It is surprising that business and shopping came out . equal. One would expect business to be a more common reason for coming to South Florida. The business traveler is exposed to the same accommodations as the tourist and it is therefore very important to make a favorable impression upon him so that he will bring his family back with him.

It has always been known that shopping was an important reason for the Latin tourist to come to South Florida. Many of the goods here are impossible to buy in South America and it is not uncommon for the Latin tourist to ship back 
thousands of dollars worth of merchandise. The shopping facilities in Miami are excellent and are getting better all the time. This is one area in which Miami has kept a steady pace with the Latin American tourist's needs.

3. What is the average length of your stay in Miami?

$$
\begin{array}{lll}
\text { a. } 2 \text { days } & \frac{5.75}{6} & \text { d. } 8-14 \text { days } \\
\text { b. } 3-4 \text { days } & \frac{16.09}{21.84} \% & \text { e. More than } 14 \text { days } \\
\text { c. } 5-7 \text { days } & \underline{21}
\end{array}
$$

This question was used mainly to gain some insight into the average length of stay. More than half of the tourists: reported staying longer than one week. Almost $28 \%$ acknowledged staying more than two weeks. The average stay for all tourists, both domestic and international, was 9.6 nights. The Latins averaged a slightly longer stay than the domestic tourists.

4. Is your income...

a. Low (under $\$ 20,000$ per year)

$21.84 \%$

b. Medium (from $\$ 20,001$ to $\$ 40,000$ per year) $\underline{50.57} \%$

c. High $(\$ 40,001$ and above per year)

This question is pretty straight forward and at this point, does not warrant in-depth discussion. When the total survey is broken down into the different groups, this question will take on more importance. It is interesting to note that 
the percentages for income breakdown in this survey were almost exactly the same as those done in a study by the MetroDade Tourism Department.

5. Would you favor the legalization of casinos in Miami?
a. Yes
$63.22 \%$
b. No $\frac{28.73}{8.05 \%}$
c. Indifferent

This is probably the most important question of the survey and one which had a surprising response. $63.22 \%$ of the Latin tourists polled said that they would favor legalization of casino gambling in Miami. 8.058 were indifferent while only $28.73 \%$ were opposed to casinos in Miami.

The survey shows a clear majority in favor of casinos in Miami. It is obvious that should casinos become legal, they could expect to draw patronage from the Latin tourist market. The author felt that casinos would be welcomed by the Latin tourist but not to this extent!

The $28.73 \%$ who opposed casinos comprise a smaller percentage than anticipated. Although $28.73 \%$ seems small, it is important to ask whether those tourists would stop coming to Miami if casinos were legalized. This shall be discussed later. The most important thing to note at this point is that a 
clear majority of Latin tourists do favor the legalization of casino gambling in Miami.

6. If casinos were legalized, would you come to Miami more often?

If yes, how many more times? If no, would this stop you from returning?

a. Yes $52.87 \%$

At least one more time a year....41.31\%

Two times a year............

Three times a year...........

b. No 47.138

Yes, they would not return.......18.35\%

No, they would return anyway.....

In this question, we also have a majority of $52.87 \%$ responding positively to the question. This is also an important question because it is assessing whether the addition of casinos to Miami would induce the tourist to return more frequently. of the $52.17 \%$ responding yes, $41.31 \%$ would come at least once every year, $52.17 \%$ would come at least twice a year and 6.578 would come three times a year.

It is significant to note that the majority would come back to Miami more often if casinos were legalized. This. implies that they must feel casinos are an important part of their entertainment plans and that they could prove to be a powerful new attraction for the Miami tourist industry. 
It also suggests that they are probably going to other places where casino gambling is legal.

On the other side of the question, $47.17 \%$ said they would not come back more often. A very important figure here is the fact that only $8.45 \%$ said that they would not return to Miami should casinos become legal. It would seem that of the total responses; only $8.45 \%$ would be so turned off by casinos that they would not return. Again, it seems as if casino gambling could prove to be very positive to the Latin tourist flow.

7. How much do you usually spend in your visits to Miami, besides that money spent on airfare?
a. Under $\$ 500.00$
b. From $\$ 501.00$ to $\$ 1,000.00$
19.538
c. More than $\$ 1,000.00$
$\underline{57.47} \div$

This question is again basically for imformation purposes. Almost $60 \%$ of those polled spent more than $\$ 1,000.00$. When reviewing this question, Mr. Rosen expressed doubt as to whether the average Latin tourist would answer this question truthflly, since each country puts restrictions on how much is.

a toufist can spend on material goods that are to be brought back home. The author disagreed, since the question did 
ask for a specific figure, only whether it was more or less than $\$ 1,000.00$. When the survey was done, the author's assistant fully explained the purpose of the study and noted that is was not a government sponsored survey.

8. How much would you spend on gambling if it were available?
a. Nothing
$\frac{37.93 \%}{6.9 \%}$
e. About $\$ 400.00$
b. About $\$ 100.00$
$1 \frac{6.9}{2.64} 8$
c. About $\$ 200.00$
$\underline{10.35 \%}$
f. About $\$ 500.00$.
d. About $\$ 300.00$
g. More than $\$ 1,000.00$

This question pointed out some interesting facts. $37.93 \%$ said they would spend nothing if gambling were legal, yet, only $28.73 \%$ were not in favor it it. Thus, 98 of those who would like to see casinos would not spend any money gambling. Maybe, they would go to the casinos for the shows or maybe they feel that casinos would provide the money and incentive to build up the hotels and other attractions.

Mr. Rosen stated that a profile of the typical gambler in Atlantic City was a person over 45, female, and who spent between $\$ 50.00$ to $\$ 60.00$ total on gambling. It appears that the Latin profile is much different. If they are going to gamble at all, most are going to spend more than $\$ 100.00$ and 31.8 are going to spend more than $\$ 400.00$. Of that $31 \%$, more than half are going to spend over $\$ 500.00$. 
9. Where have you gone to gamble in the past?
a. Aruba
b. Panama
$\frac{5.748}{8.05 \%}$
d. Nowhere
c. Las Vegas
$\underline{18.39} 8$
e. Atlantic City
$\frac{45.97 \%}{3.45 \%}$
f. Bahamas, Aruba \& Las Vegas
g. Aruba, Las Vegas \& Atlantic City
$\frac{1.15 \%}{1.15 \%}$
h. Bahamas \& Panama
$3.45 \%$
i. Bahamas \& Aruba
1.158
j. Aruba \& Las Vegas
k. Las Vegas \& Panama
$\frac{1.45}{3.48}$
1. Curacao
m. Aurba \& Atlantic City
n. Bahamas, Las Vegas \& Panama
- Aruba, Las Vegas, Panama and Bahamas
2.38
p. Aruba, Las Vegas \& Panama
$1.15 \%$
$1.15 \%$
1.158
1.158
$1.15 \%$

When asked where they had gone to gamble in the past, $45.97 \%$

said nowhere. Thus, $17 \%$ of the people who would favor the legalization of casinos in Florida have never gambled anywhere before. Las Vegas was by far the most popular spot for gambling by the Latin tourist with 18.398 . Panama follwed with 8.058 , Aruba $5.74 \%$ and Atlantic City only $3.45 \%$. It would appear that Atlantic City has not done much to attract the Latin tourist. It is interesting to note that no Latin tourist has only been to the Bahamas to gamble, exclusively. If they gambled in the Bahamas, they always had been somewhere else. The rest of the percentages show a breakdown of the various combinations of locations where these people gambled in the past. 
10. What would make your stay in Miami more pleasureable?
a. Nothing
$\frac{60.92 \%}{17.24 \%}$
e. More attractions
b. Gambling
$\frac{17.24}{10.348}$
f. Better hotels
$\frac{2.38}{2.38}$
c. Less crime
g. Faster airports
$1.15 \%$
d. Better food
$3.45 \%$
h. Cleaner beaches
$1.15 \%$
i. Lower prices
$1.15 \%$

The author feels that this is a very important question because it allowed the Latin tourist to write in his own feelings. The question had no answers, just several blank lines on which to write. It was interesting that the responses came out so uniform in that they could have written in anything that they pleased.

About $60 \%$ said nothing could enhance their stay. That is a positive answer for the tourist industry in Miami. Somebody did something right. $17 \%$ felt the need to state gambling even though that was the focus of the survey. So much for the positive responses.

$10 \%$ felt that crime was one problem that Miami had a long" way to go to solve. $3.45 \%$ were not satisfied with the food, while $2.3 \%$ felt that better hotels were needed. High prices, a slow airport and dirty beaches also were mentioned as needing improvement. Finaliy, $2.3 \%$ wanted to see more attractions. 
These are the things that the tourist industry must start paying attention to if we are to keep the Latin market happy. As mentioned before, the latin market is important. The Latin market grew by $8.58 \%$ in 1982 while the domestic and European markets declined. 40 It is easy to understand why the Latin market must be given more attention now and in the future.

In the next section of this paper, the results of each of the different groups of Latin American tourists will be analyzed. The first sample to be studied will be the Venezuelan tourist.

\section{THE VENEZUELAN RESULTS}

1. What nationality are you? Venezuelan

Venezuela is by far the largest Latin American tourist market. for South Florida providing 276,316 tourists in 1981 .

2. What is the main purpose of your visit?
$\begin{array}{ll}\text { a.: Pleasure } & 55.82 \% \\ \text { b: } & \text { Business }\end{array}$
C. Pleasure \& business
d. Pleasure \& shopping
$\underline{4.65} \%$
e. All of the above
$18.6 \%$ 
Pleasure is the major purpose of the Venezuelan tourist, accounting for 55.82\%. Business takes up $16.28 \%$ while pleasure and business, and business and shopping accounts for $18.6 \%$. It is interesting to note that not one Venezuelan listed shopping as the major reason for visitng Miami.

3. What is the average length of your stay in Miami?
a. 2 day
b. 3-4 days
$\underline{2.33} 8$
d. 8-14-days
c. 5-7 days
$1 \overline{1.63} \%$
e. More than 14 days
$\frac{34.88}{34.88} \%$

The Venezuelans stayed longer than both the Colombians and the Mexicans. 698 stay longer than one week. This is a sign of a vacation stay opposed to a business stay. Since they: stay longer, it naturally follows that they spend more, which will be proven in a later question.

4. Is your income bracket...
a. Low (under $\$ 20,000$ per year)
b. Medium (from $\$ 20,001$ to $\$ 40,000$ per year)
c. High $(\$ 40,001$ and above per year)
$\frac{16.28 \%}{46.51}$

Venezuela also had the most respondants in the high income bracket-37\%. $46.51 \%$ are in the medium bracket leaving only $16.28 \%$ in the lower income bracket. Venezuela is a country rich with Petro dollars and maybe this explains the high proportion of upper income respondants. 
5. Would you favor the legalization of casinos in Miami?
a. Yes
$\frac{65.12 \%}{25.58 \%}$
b. No
$25.58 \%$
c. "Indifferent
$\underline{9.38}$

$65.12 \%$ said that they would favor legalization of casinos $25.58 \%$ said no and $9.3 \%$ were indifferent. Mr. Aranguran, the Consul General of Venezuela, told the author that most Venezuelans love to gamble and that it is an important part of life in Venezuela. The Venezuelans support the legalization of casino gambling in Miami, overwhelmingly.

6. If casinos were legalized, would you come to Miami more often?

If yes, how many more times? If no, would this stop you from returing?

a. Yes $53.49 \%$

At least one time a year....30.43\%

: Two times a year...........

Three times a year...........

B. No 46.518

Yes, they would not return........

No, they would return anyway.....100\%

53.49 said they would come to Miami more often if casinos were legal. Almost $70 \%$ of those would come two or more times a year. $46.51 \%$ would not come more often. With gambling being such an important part of Venezuelan life, it is natural that they would come to Miami more often. It would appear 
that casino gambling in Miami would prove to be a strong inducement for Venezuelans to visit Miami and to return again. Not one of the $46 \%$ who said no would frequent Miami less if casinos were legalized.

7. How much do you usually spend in your visits to Miami, besides that money spent on airfare?

$$
\begin{array}{lll}
\text { a. Under } \$ 500.00 & \frac{13.95 \%}{25.58} \% \\
\text { b. } \$ 501.00 \text { to } \$ 1,000.00 & \underline{60.47} \% \\
\text { c. More than } \$ 1,000.00 &
\end{array}
$$

The Venezuelans spend a lot of money in Miami when they visit. $60.47 \%$ spend more than $\$ 1,000.00$. $25.55 \%$ spend from $\$ 500.01$ to $\$ 1,000.00$ and only $13.95 \%$ spend less than $\$ 500.00$. This corresponds to the longer than average length of stay and the high income of the Venezuelan tourist. The Venezuelans spend more than any other group. They make up the largest group and they stay, on the average, longer than both the Colombians and the Mexicans.

8. Ho much would you spend on gambling if it were available?

$\begin{array}{llll}\text { a. About } \$ 100.00 & \underline{9.3} 8 & \text { d. About } \$ 500.00 & \frac{13.95}{23.37} \\ \text { b. About } \$ 200.00 & \underline{9.3} 8 & \text { e. More than } \$ 1,000.00 \frac{\underline{9.3} 8}{34.88}\end{array}$

$34.88 \%$ of the Venezuelans would spend nothing if casinos were legal in Miami. The Venezuelans had the largest group 
to spend about $\$ 100.00$ and the largest to spend more than $\$ 1,000.00$. To be exact, $23.27 \%$ would spend more than $\$ 1,000.00$. Again this corresponds to the higher income.

9. Where have you gone to gamble in the past?

$\begin{array}{llll}\text { a. Aruba } & \frac{9.3 \%}{6.98} \% & \text { d. Nowhere } & \underline{37.21} \% \\ \text { b. Panama } & \underline{\underline{6.98}} \% & \text { e. Atlantic City } & \underline{6.33} \% \\ \text { c. Las Vegas } & \underline{18.60} & \text { f. Curacao }\end{array}$

$\begin{array}{ll}\text { g. Bahamas, Las Vegas \& Panama } & \underline{2.33} \% \\ \text { h. Aruba, Las Vegas \& Panama } & \underline{2.33} \% \\ \text { i. Las Vegas \& Panama } & \underline{2.33} \% \\ \text { j. Aruba \& Las Vegas } & \underline{\underline{4.62}} \% \\ \text { k. Aruba \& Atlantic City } & \underline{2.33} \% \\ \text { 1. Bahamas, Las Vegas, Aruba \& Panama } & \underline{2.33} \% \\ \text { m. Bahamas \& Panama } & \underline{2.33}\end{array}$

Las Vegas is the place that 18.608 of the Venzuelans have gambled. This is surprising since Aruba, with only 9.3\% is right off the coast of Venezuela. The Venzuelans also seens to have been to Atlantic City more than the Colombians and the Mexicans, Again, $37 \%$ of the people had not gambled anywhere but $65 \%$ want gambling in Miami. 唡

10. What would make your stay in Miami more pleasurable?
a. Gambling
$\frac{13.95 \%}{11.63 \%}$
d. Faster airports
b. Less crime
e. More activities.
$\frac{2.33}{4.65 \%}$
c. Better hotels
f. Nothing
65.118

The Venezuelan seems to be the happiest with Miami.

$65.11 \%$ said nothing would make their stay more pleasant. 
$11.63 \%$ still thought crime was a problem. New hotels and a faster airport were noted by $2.33 \%$. Gambling was mentioned by $13.95 \%$ of the Venezuelans as something that would make their stay more pleasurable.

\section{THE COLOMBIAN RESPONSE}

1. What nationality are you? Colombian

The Colombians made up $17.33 \%$ of the total Latin American market that visited South Florida in 1981. In this survey, they comprised $33.33 \%$ of the total respondants.

2. What is the main purpose of your visit?
a. Pleasure
$\frac{55.17 \%}{34.48} \%$
c. Shopping
b. Business
d. All of the above
$\frac{3.458}{6.98}$

The Colombians had the highest percentage of business oriented visits of all the countries. This is confirmed by the highest percentage of short visits of any country. Again, about $55 \%$ of the visits were pleasure oriented. Shopping was named by $3.45 \%$ to be the major purpose of the visit while about $7 \%$ came for all reasons.

3. What is the average length of your stay in Miami? 

a. 2 days
$\frac{10.34 \%}{20.69 \%}$
d. 8-14 days
b. 3-4 days
$\frac{20,69}{27.59}$
e. More than 14 days
$\frac{20.69}{20.698}$
c. 5-7 days
$\underline{27.59} 8$

The most significant figure here is the 10.34 for a two day stay. This is the largest percentage of short stays of all the groups. About $41 \%$ stay longer than a week while almost $59 \%$ stay less than one week. The bottom line is that the Colombians stay fewër days than any other group.

4. Is your income bracket...
a. Low (under $\$ 20,000$ per year) 20.698
b. Medium (from $\$ 20,001$ to $\$ 40,000$ per year)
51.728
c. High $(\$ 40,001$ and above per year) $\underline{27.59} 8$

The Colombian income breakdown parallels that of the Venezuelan, except that the Venezuelan has $10 \%$ more in the high bracket while the Colombian has $4.5 \%$ more in the low: bracket and $4.5 \%$ more in the middle income bracket.

5. Would you favor the legalization of casinos in Miami? $\begin{array}{ll}\text { a. Yes } & \frac{48.28 \%}{48.28} \% \\ \text { b. No Indifferent } & \underline{3.44} \%\end{array}$

The Colombians are completely divided on the issue of casino gambling with $48.28 \%$ responding yes, $48,28 \%$ responding no and only 3.44 remaining indifferent. This was the only. 
group that was not clearly in favor of casino gambling in Miami. Again, it is important to note that Colombia has casinos and, therefore, it would not be so new an attraction to the tourists who visit Miami.

6. If casinos were legalized, would you come to Miami more often?

If yes, how many more times? If no, would this stop you from returning?

a. Yes $41.38 \%$

At least one time a year....58.33\%

Two times a year..........

b. No $\underline{58.62 \%}$

Yes, they would not return $\quad 17.65 \%$

No, they would return anyway.... $\overline{82.35} 8$ $\therefore$

The most significant factor is that $17.65 \%$ of the $58.62 \%$ who said they would not come more often, would not return to Miami should casinos become legal. No other group expressed this feeling. It is reasonable to assume that should casinos become legal in Miami, some Colombians would not return. But, that number would prove insignificant compared to the overall positive response of the total Latin market. The Colombians also had the fewest who would return should casinos be legalized. Only $41.38 \%$ would come more often. $58.33 \%$ would come at least once a year while $41.67 \%$ would come at least twice. None would come three times. 
This might be explained by the fact that Colombia has casino: gambling in several cities.

7. How much do you usually spend in your visits to Miami, besides that money spent on airfare? at.
a. Under $\$ 500.00$
b. $\$ 501.00$ to $\$ 1,000.00$
$\frac{27.59}{13.79} \%$
c. More than $\$ 1,000.00$
$\underline{58.62} \%$

The Colombians had the largest percentage group which spent under $\$ 500.00$ per visit-27.59\%. Yet, $58.62 \%$ spent more than $\$ 1,000.00$ per visit. This figure was second to the Verfezuelans. The large percentage of persons that spent under $\$ 500.00$ is probably due to the high number of business travelers whose companies provide for expenses.

8. How much would you spend on gambling if it were available?
a. About $\$ 100.00$
6.98 e. About $\$ 500.00$
b. About $\$ 200.00$
$\frac{10.34}{13.79} \%$
f. More than $\$ 1,000.00$
$\frac{\frac{6.9}{8}}{10.34}$
c. About $\$ 300.00$
g. Nothing
d. About $\$ 400.00$
3.458

The Colombian group was the only one where everyone who favored casinos would actually spend some money on gambling $(48.28 \%)$. 10.34\% would gamble more than $\$ 1,000.00$. About $42 \%$ would spend less than $\$ 500.00$, but everyone who favored gambling would spend something. 
9. Where have you been to gamble in the past?
a. Las Vegas
b. The Bahamas \& Aruba
c. Aruba \& Ias Vegas
d. The Bahamas \& Panama
e. Aruba, Las Vegas \& Atlantic City
f. The Bahamas, Aruba \& Las Vegas
g. Nowhere
$\frac{\frac{10.33}{3.45} \%}{\frac{3.45}{6.9 \%}}$

The Colombians saw the least of Las Vegas and were also the largest group to not have gambled anywhere before-65.52\% If they had gambled someplace besides Las Vegas, they had also gambled at more than one location.

10. What would make your stay in Miami more pleasurable?
a. Gambling
b. Less crime
$\frac{13.79}{13.79} \%$
e. Lower prices
c. Better hotels
$3.45 \%$
d. Better food
$\underline{3.45} \%$
f. Cleaner beaches
g. Nothing

The Colombians were more concerned with crime than any other group-13.79\%. Better hotels, better food, cleaner beaches, and lower prices would have made about $11 \%$ of the people more happy. 58.628 could think of nothing to make this visit more pleasurable, while 13.798 mentioned gambling as being one attraction that would make their stay more pleasurable. 
1. What nationality are you? Mexican

The Mexicans accounted for $15 \%$ of the total Latin tourist market who visited Miami in 1981. In this survey, they represented $17.24 \%$. It is important to note that they have been increasing the tourist flow to Miami over the past several years.

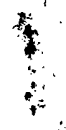

2. What is the main purpose of your visit?
a. Pleasure
$\frac{66.66 \%}{20.0}$
c. Shopping
b. Business
d. All of the above

$\mathrm{F}$

The Mexicans had the largest group of pleasure oriented tourists $-66.66 \%$. $20 \%$ came for business reasons, $6.67 \%$ for shopping and $6.67 \%$ for all of the above. The fact that they chose to come to Miami instead of California is significant. The Mexicans proved to be a very different group than both the Colombians and the Venezuelans.

3. What is the average length of your stay in Miami?
a. 2 days
6.668
d. 8-14-days
b. 3-4 days
e. More than 14 days
$\frac{26.67 \%}{20.0} 8$
c. 5-7 days
$\underline{26.67} \%$

The Mexicans stayed for longer visits than the Colombians with $46.67 \%$ staying more than one week. There is a possibility that many of the Mexican tourists stay with relatives while 
visiting Miami. This might not be the case, but what can explain the discrepancy between the length of stay and monies spent?

4. Is your income bracket...

a. Low (under $\$ 20,000$ per year)
b. Medium $(\$ 20,001$ to $\$ 40,000$ per year)
c. High $(\$ 40,001$ and above per year)

The Mexicans had no one in the high income bracket. They had approximately $20 \%$ more in the lower income bracket. They also accounted for the largest group of middle class tourists-60\%. Maybe this can be explained by the fact that airfare is less from Mexico to Miami than from the other countries and thus, the lower income group can better afford to come $* *$ here.

5. Would you favor the legalization of casinos in Miami?:
a. Yes
$\frac{86.67 \%}{0.0 \%}$
b. No
c. Indifferent $\underline{13.33} \%$

There is no question about whether the Mexicans want to see casinos in Miami. $86.67 \%$ were in favor of them.

13.33\% were indifferent to the issue of casino gambling

but none opposed it. It would seem to be fair to say that 
casinos would attract the Mexican tourist which is quickly catching up, in total tourists per year, with colombia.

6. If casinos were legalized, would you come to Miami more often?

If yes, how many more times? If no, would this stop you from returning?

a. Yes $73.33 \%$

At least one time a year....45.46\%

Two times a year..........

Three times a year..........

b. No $\underline{26.67 \%}$

Yes, they would not return..... $0.0 \%$

No, they would return anyway.... 100.0 8

The Mexicans would come more often to Miami if casinos were legal. $73.33 \%$ said yeș, while only $26.67 \%$ said No. of that $73.33 \%$, nearly $55 \%$ would come two or three times a year. Of course, the current financial problems that now face Mexico are far from resolved, but someday, that will change. Casinos in Miami could prove to be a big tourist draw for the Mexican market.

7. How much do you usually spend in your visits to Miami, besides that money spent on airfare?
a. Under $\$ 500.00$
$\frac{20.0}{33.33} 8$
b. $\$ 501.00$ to $\$ 1,000.00$
$\underline{46.67} \%$ 
The Mexican market spends a lot of money in Miami, considering that none of its tourists are in the high income bracket. In fact, $46.67 \%$ of the Mexican tourists spend more than $\$ 1,000.00$. This is only $12 \%$ less than the Colombian market.

8." How much would you spend on gambling if it were available?
a... About $\$ 100.00$
$\frac{\frac{0.0}{26.67} \%}{6.67} \%$
d. About $\$ 500.00$
b. About $\$ 200.00$
e. More than $\$ 1,000$
$\frac{33.32}{6.67}$
c. About $\$ 300.00$
f. Nothing
26.67

Here, it seems the Mexicans are a little more conservative with their money. $26.67 \%$ would spend nothing, therefore, some who would like to see casinos in Miami would no necessarily spend any money gambling. Only $6.67 \%$ would spend more than $\$ 1,000.00$. This is the smallest group of the Latin market studied. $33.33 \%$ would spend about $\$ 500.00$ and $26.67 \%$ about $\$ 200.00$.

9. Where have you gone to gamble in the past?
a. Las Vegas
$\underline{33.33} \frac{8}{26.67} \%$
c. Las Vegas \& Panama
b. Panama
d. Nowhere
$\underline{3.67}$

The Mexicans have the largest group of people who have gambled in Las Vegas, 33.33\%. They also have the largest group to have gambled in Panama-26.67\%. And finally, they have 
fewer people who have gambled nowhere than both the Colombians and the Venezuelans.

10. What would make your stay in Miami more pleasurable?
a. Gambling
b. Better food
$33.33 \%$
c. Nothing
13.338
53.348

It seems that the Mexicans were not bothered by crime or the condition of the hotels. $13.33 \%$ would like to see better food, while $53.34 \%$ could think of nothing to make their visit more pleasurable. $33.33 \%$ stated they wanted to see casinos, which is the largest of any group. 


\section{THE HYPOTHESIS}

The hypothesis is that the typical Latin American toutist a.

would consider legalized casino gambling to be a positive inducement to vacation in Miami or return for future visits. Through the survey, the author attempted to gain a representative sample "of the Latin tourist market and to determine, through the sample, the feelings of the entire Latin American tourist market.

The results of the survey showed that $63.22 \%$ of the Latin tourists would favor the legalization of casinos in " Miami. This is a clear majority. The survey also showed that $8.05 \%$ of the Latin tourists were indifferent to legalized casinos.: Only $28.73 \%$ would not favor casinos.

The Latin tourist market also responded positively to the question asking, "if casinos did become legal, would you come to Miami more often?" $52.87 \%$ of the tourists replied that they would come to Miami more often. Of the total $52.87 \%$, 41.318 would come at least once every year, 52.17 would come at least twice a year and $6.5 \%$ would come three times a year. 
Out of the $47.13 \%$ who stated that they would not come to Miami more often, only $8.35 \%$ said they would come less frequently. That is a very small percentage of the whole Latin market and this points out that all in all, there very few Latins who would actually be offended if casinos were legalized in Florida. The author concluded that this is a very favorable response and one that, again, proves the thesis.

At this point, the author would like to make several projections relating to the number of tourists returning to Miami, should casinos become legal. In 1981, the total Latin tourist market consisted of $1,088,144$ tourists. ${ }^{41}$ In the survey, $52.87 \%$ stated they would come to Miami more often, thus, 575,301 tourists would come more often. Of this $575,301,41.31 \%$ would come at least once every year. Thus 237,657 would come once every year. 52.17\% of the 575,301 would come twice a year, which would amount to 600,268 more a year. Finally, $6.52 \%$ of the 575,301 would come three of more times a year, which would amount to 112,528 visitors $?$ per year. The total number of tourists visiting Miami per year, due to casino gambling, would be 950,453 . That's onfy 137,671 less tourists than the total 1981 figure. This is: not counting new visitors, only repeat tourists. 
Granted, this is just a projection and is subject to many variables, such as, the world economy, each country's economy and travel restrictions, just to name a few. The implications are staggering. The economic impact on Miami could be tremendous.

The hypothesis states that casino gambling would have a positive effect on the Latin American tourist. The survey points out that this is true. The hypothesis is valid.

\section{OTHER FINDINGS}

Several other ideas presented themselves through the study. Because the Latin American tourist would favor casinos and would come to visit more often, the Miami-economy would ultimately benefit. The exact amount of money generated by casinos through the Latin American tourist cannot really be accurately projected, the author believes the impact would be significant and would be felt throughout the South Florida economy. Hotels, restaurants and retailers would all feel the impact.

Through the Latin tourist, Miami could watch its tourist flow change from seasonal to year-round. Of course, in order for this to happen, many of the complains set forth by the 
Latin tourists would have to be dealt with. Casinos could mean better hotels nad restaurants. More attractions could certainly be built with the additional income. The beaches could be cleaned up and the airport incoming and departure procedures could be improved. Crime would have to be kept under tight control. All of these issues could be adequately dealt with should casinos become legal.

If the Latin tourist found a new Miami, it might well prove"to be "The" vacation stop for the Latin American market. A new Miami could come about with the help of casino gambling. The Latin American tourist would like to see casinos in Miami. If casinos were legal, it would have a positive effect on the Latin tourist market and that is the bottom line. 


\section{SUMMARY AND CONCLUSION}

This thesis was undertaken to determine the probable effects that casino gambling might have on the Latin American share of the tourist market, located in Miami, Florida. The survey, which was undertaken in order to find out the answer to the question, was done in an unbiased way. The researcher, after compiling the results of the survey, concluded that the overall Latin tourist market would favor the legalization of casinos in Miami and that legalization would have a substantial impact on the tourist flow. An increase in the latin American tourist flow would mean more dollars spent in Miami. This would benefit the Miami tourist industry and also the citizens of South Florida.

Miañi tourism is not what it used to be and is declining at an alarming rate. The tourist industry is plagued by aging hotels and competition from attractions such as Disney World and the casinos in the Bahamas. Domestic tourist flow has been declining, in recent years, while the international and specifically, the Latin American tourist flow, has been incresasing. But what keeps the Latin market coming back? 
The pro-casino forces say that casincswould bring tourist dollars, convention business, property taxes and construction developments, all lending to a revitalization of the Miami tourist industry. The anti-casino forces feel that casinos would bring organized crime and street crime to Miami with great force. This paper, although briefly discussing both issues, is not concerned with what casinos could do for Miami, whether good or bad, but rather what it could do for the Latin American tourist market. The author concludes that the question has been answered by this thesis and that casino gambling would have a positive effect on the Latin share of the tourist market located in Miami, Florida. 4

RECOMMENDATIONS

It will be interesting to see how the issue of legalized casino gambling fairs in the coming election. Although the pro-casino forces promise a tough battle, the opposition has always come through in the past. If casinos do not win legalization, what will become of the Miami tourist industry? Will something else save it?

One positive result that arose from this paper is that the leaders of both the pro and anti-casino forces 
have been exposed to the Latin tourist market question. When the author first inquired, neither had really considered of whether either side will make an issue out of it. Only time will tell.

Through researching this paper, the author discovered that the Latin tourist market had received very little attention. The lack of published information about such an important tourist market is unacceptable. More research is needed in this area and should prove to be a rewarding topic of study for any hospitality student concerned with the tourist industry of Miami. 


\section{A SELECTED BIBLIOGRAPHY}

"Atlántic City Gambling Loses its Glow." Business Week, January 26, 1981.

"Atlantic City's Struggle Against the Mafia." U.S. News and World Report, April 13, 1981.

Ferguson, Robert R.J. "Casino Gambling: A Market to Watch in the 80's." Lodging, February 1980.

"Gambling Fever." Changing Times, September 1977.

"Gold Coast Gambling." Time Magazine, September 18, 1978.

Luytjes, Jan B. The Econonic Impact of Legalized Gambling on South Florida. Florida International University, School of Business and Organizational Sciences, 1976.

Leedy, Paul D. Practical Research Planning and Design. New York: Macmillan Publishing Co., Inc., 1980.

Melton, Eastor; Patrick Riordan. "Casinos Out for Florida this Year." Miami Herald,

"Organized Crime and Gambling." First Interim Report of the Commission on the Review of the National Policy Toward Gambling. Washington, D.C.: United Printing Office, 1975 .

Riordan, Patrick; Bass, Allen. "Pro-Casino Forces Mount New Referendum Drive." Miami Herald, Tuesday, May 4, 1982.

"Should Florida Take the Casino Gamble?" Florida Trend, July 1978.

"Travel Trends Annual Report, January-December 1981." Metro Dade County Department of Tourism, March 1982.

"What Gambling Does for-and to-Las Vegas." U.S. News and World Report, March 9, 1981.

Wooten, James R. "Sunny Florida; Foreshadowing our Future." U.S. News and World Report, January 9, 1978. 
FOOTNOTES

1. "Travel Trends Annual Report, January-December, 1981," Metro Dade County Department of Tourism, March 1982.

2. Robert R. J. Ferguson, "Casino Gambling: A Market to' Watch in the $80 \mathrm{\prime}$," Lodging, February 1980.

3. "Gambling Fever," Changing Times, September 1977.

4. Ibid.

5. Ibid.

6. Ibid.

7. Ibid.

8. "Organized Crime and Gambling," First Interim Report of the Commission on the Review of the National Policy Toward Gambling (Washington, D.C.: United Printing Office, 1975).

9. Ibid.

10. "What Gambling Does for-and to-Las Vegas," U.S. News and World Report, March 9, 1981.

11. Ibid.

12. Ibid.

13. Ibid.

14. Ibid.

15. "Atlantic City's Struggle Against the Mafia," U.S. News and World Report, April 13, 1981.

16\% "Atlantic City Gambling Loses its Glow," Business Week, January 26, 1981.

17. "Atlantic City's Struggle Against the Mafia." 
18. Ibid.

19. Ibid.

20\%" "Gold Coast Gambling," Time Magizine, Sept. 18, 1978.

21: Jan B. Luytjes, The Economic Impact of Legalized Gambling on South Florida (Florida International University, School of Business and Organizational Sciences, 1976).

22. James R. Wooten, "Sunny Florida; Foreshadowing our Future," U.S. News and World Report, January 9, 1978.

23. Luytjes, The Economic Impact of Legalized Gambling on South Florida.

24. Ibid. :

25. Ibid.

26. Ibid.

27. Ibid.

28. "Travel Trends Annual Report, January-December 1981."

29. Ibid.

30. Ibid.

31. "Should Florida Take the Casino Gamble?" Florida Trend, July 1978 .

32. Patric Riordan and Allen Bass, "Pro-Casino Forces Mount New Referendum Drive," Miami Herald, May 4, 1982.

33. Eastor Melton and Patrick Riordan, "Casinos out for Florida this Year," Miami Herald,

34. Ibid.

35. Ibid

36. Lutyjes, The Economic Impact of Legalized Gambling on South Florida. 
37. Ibid.

38. Ibid.

39. Paul D. Leedy, Practical Research Planning and Design. New York: Macmillan Publishing Co., Inc., 1980.

40. "Trave1 Trends Annual Report, January-December 1981."

$\therefore$ 41. Ibid.

42. Ibid.

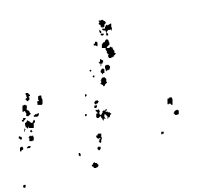




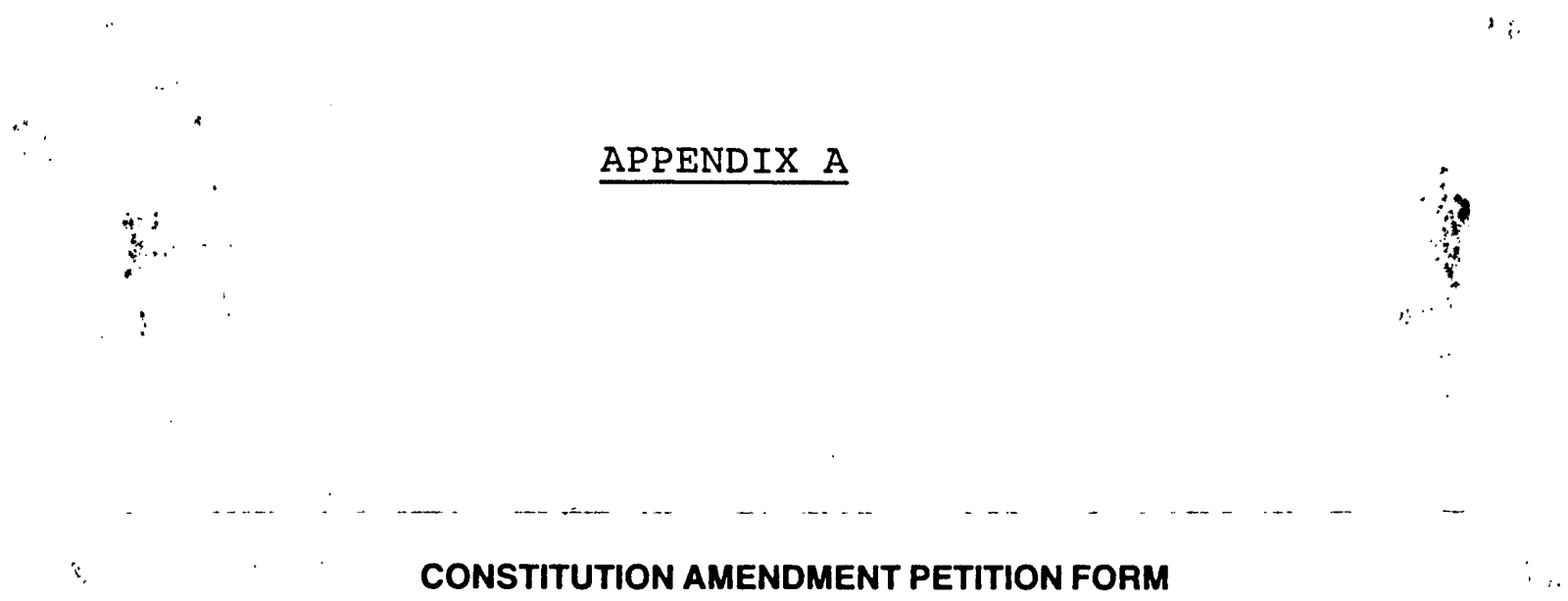

104.185 - It is unlawtul for any person to knowingly sign a petition or petitions for a particular issue or candidate more than one time. Any person violating the provisions of this section shall, upon conviction, be guilty of a misdemeanor of the first degree, punishable as provided in s. 775.082 , s. 775.038, or s. 775.084 .

Name

Please Print Name as it Appears on Voting Roll

Precinct No. County

Street Address 3 City

I am a registered voter of Florida and hereby petition the Secretary of State to place the following amendment to the Florida Constitution on the ballot in the next general election held more than 90 days after filing with the Secretary of State of a petition or petitions containing a copy of said amendment and signed by the number of electors required by Article XI, Sec. 3 of the Florida Constitution.

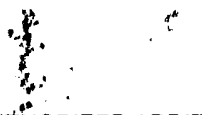

SECTION 15. AUTHORIZED ADDITIONAL FORMS OF GAMBLING

(a) The conduct and operation of casino gambling and other forms of gambling specified in this section are hereby authorized.

(b) Casino Gambling as hereby authorized shall include those gaming activities commonly known as baccarat, blackjack or twenty-one, craps, keno. poker, roulette and french roulette, and slot machines, and shall include such additional gaming activities as may be permitted by general law. The operation of a lottery or lotteries. other than bingo, shall also be permitted as a casino gaming activity: provided. however, by general law, the concurrent or exclusive right to conduct a lottery or lotteries may be reserved to the state.

(c) In addition to operation as a casino gaming activity. the operation of slot machines upon properties licensed for pari-mutuel wagering is hereby authorized. Except as specifically provided in this subsection, this section shall neither apply to nor affect the authorization, licensing or conduct of pari-mutuel wagering in the state.

(d) Casino gambling may be conducted only upon properties designated as "authorized casino sites". Authorized casino sites may be approved and designated only as follows:

Paid Political Advertisement Paid for by Citizens for Less Taxes
(1) In all counties, authorized casino sites may be approved and designated by general law, general law of local application, or special law.

(2) In BAY, BROWARD, COLLIER, DADE. DUVAL, HILLSBOROUGH, LEE, MONROE. OKALOOSA, ORANGE. PALM BEACH, PINELLAS, and VOLUSIA Counties, and in any county which has by referendum approved the conduct and operation of casino gambling within said county, authorized casino sites may be designated and approved by a vote of the electors of the respective counties pursuant to established voting procedures in said respective counties.

(3) The following eleven properties located in BAY. BROWARD. DADE. HILLSBOROUGH. MONROE, OKALOOSA. PINELLAS and VOLUSIA Counties are hereby designated and approved as authorized casino sites: Holiday Inn Beachside. 12907 West 98. Panama City Beach. Bay County: Beach Club Hotel, 3100 North Ocean Boulevard. Fort Lauderdale. Broward County; Holiday Hotel. 3050 Holiday Drive. Fort Lauderdale, Broward County; Castaways Beach Club, 16375 Collins Avenue. Sunny Isles, Dade County: Marco Polo Hotel \& parking lot west of Collins Avenue at 192nd Street, 19201 Collins Avenue, Sunny Isles. Dade County: Waikiki Motel, including four separate and adjacent buildings with the mailing address being

CONTINUED ON OTHER SIDE 
1. What nationality are you?

$\underline{33.338}$ Colombian $\quad \underline{49.438}$ Venezuelan $\quad \underline{17.248}$ Mexican

$+4$

2. What is the main purpose of your visit?

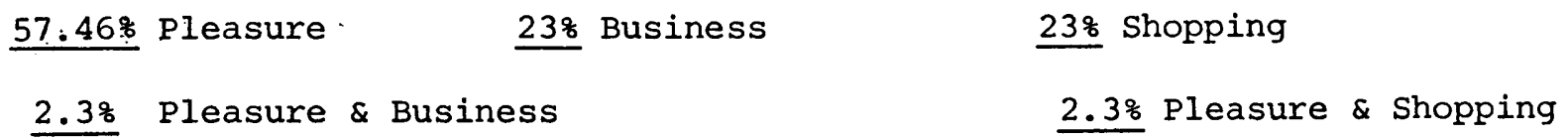

12.648 All of these

3. What is the average length of your stay in Miami?
5.7582 days
16.098 3-4 days
21.848 5-7 days
28.738 8-14 days
27.59\% More than 14 days

4. Is your income bracket...

21.848 Low (under $\$ 20,000$ per year)

50.57\% Medium (from $\$ 20,000$ to $\$ 40,000$ per year)

27.59\% High $(\$ 40,001$ and above, per year)

5. Would you favor the legalization of casinos in Miami?
63.228 Yes
28.738 No
8.05\% Indifferent 
6. If casinos were legalized, would you come to Miami more often?

If yes, how many more times? If no, would this stop you from returning?

$\frac{52.88}{5}$ Yes $\quad \underline{52.178} 2$ times a year

$\underline{6.52 \%} 3$ times a year

47.138 No

41.31\% At least one more time per year

18.358 Yes, they would not return

91.65\% No, they would return anyway

7. How - much do you usuall spend in your visits to Miami, besides that moniey spent on Airfare?

19.538 Under $\$ 500.00 \quad \underline{23 \%} 8501.00-\$ 1,000.00 \quad 57.47 \%$ More than $\$ 1,000.00$

8. How much would you spend on gambling if it were available?

: 6.98 About $\$ 100.00 \quad 12.648$ About $\$ 200.00 \quad 10.35 \%$ About $\$ 300.00$

$\underline{1.15 \%}$ About $\$ 400.00 \quad \underline{14.948}$ About $\$ 500.00 \ldots 16.09 \%$ More than $\$ 1,000.00$

$\underline{37.938}$ Nothing

9. Where have you gone to gamble in the past?

\begin{tabular}{|c|c|c|c|c|c|}
\hline 5.748 & Aruba & $18.39 \%$ & Ias Vegas & $3.45 \%$ & Atlantic City \\
\hline $8.05 \%$ & Panama & 45.978 & Nowhere & $1.15 \%$ & $\begin{array}{l}\text { Bahamas, Aruba } \\
\text { Las Vegas : }\end{array}$ \\
\hline
\end{tabular}

$\underline{1.158}$ Aruba, Las Vegas \& Atlantic City $\underline{3.458}$ Bahamas \& Panama

1.158 Bahamas \& Aruba $\underline{3.458}$ Aruba \& Las Vegas 2.38 Las Vegas \& Panama

$\underline{1.15 \%}$ Curacao $\underline{1.15 \%}$ Aruba \& Atlantic City

$\underline{1.158}$ Bahamas, Las Vegas \& Panama $\quad \underline{1.158} \begin{aligned} & \text { Aruba, Las Vegas } \\ & \text { Panama and Bahamas }\end{aligned}$

1.158 Aruba, Las Vegas \& Panama 
10. What would make your stay in Miami more pleasurable?

$\begin{array}{lll}\underline{60.928} \text { Nothing } \underline{17.248} \text { Gambling } & \underline{10.348} \text { Less crime } \\ \underline{2.38}, \text { More activities } & \underline{1.158} \text { Faster Airports } \\ \underline{3.48} \text { Better food } & \underline{1.158} \text { Clean Beaches } \\ \underline{1.158} \text { Lower prices } & \underline{2.38} \text { Better hotels }\end{array}$

$\therefore$

$\because$ 
1. What nationality are you?

\section{VENEZUELAN}

2. What is the main purpose of your visit?
a. Pleasure
55.288
c. Pleasure \& business
4.658
b. Business $16.28 \%$
d. Pleasure \& shopping
$4.65 \%$
e. All of the above
$18.6 \%$

3. What is the average length of your stay in Miami?
a. 2 days
$2.33 \%$
d. 8-14 days
$34.88 \%$
b. 3-4 days $11.63 \%$
e. More than 14 days
$34.88 \%$
c. 5-7 days 16.288

4. Is your 1ncome bracket...
a. Low (under $\$ 20,000$ per year)
$16.28 \%$
b. Medium $(\$ 20,001$ to $\$ 40,000$ per year)
$46.51 \%$
c. High $(\$ 40,001$ and above per year)
$37.21 \%$

5. Would you favor the legalization of casinos in Miami?
a. Yes
65.128
b. No
$25.58 \%$
c. Indifferent
$9.3 \%$ 
6. If casinos were legalized, would you come to Miami more often?

If yes, how many more times? If no, would this stop you from returning?

$$
\begin{aligned}
& \text { a. Yes } 53.498 \\
& \text { At least one time a year....30.43\% } \\
& \text { Two time a year...........65.228 } \\
& \text { Three times a year........ } 4.35 \% \\
& \text { b. No } 46.51 \% \\
& \text { Yes, they would not return......0.0\% } \\
& \text { No, they would return anyway...100.0\% } \\
& \therefore
\end{aligned}
$$

7. How much do you usually spend in your visits to Miami, besides that mofiey spent on airfare?

$$
\begin{aligned}
& \text { b.: Under } \$ 500.00 \\
& \text { b: } \$ 501.00 \text { to } \$ 1,000.00 \\
& \text { c\$ore than } \$ 1,000.00
\end{aligned}
$$<smiles></smiles>

8. How much would you spend on gambling if it were available?
a. About $\$ 100.00$
$\underline{9.38}$
d. About $\$ 500.00$
13.958
b. About $\$ 200.00$
e. More than $\$ 1,000.00$
23.378
c. About $\$ 300.00$
9.38
$9.3 \%$
f. Nothing
$34.88 \%$

9. Where have you gone to gamble in the past?
a. Aruba
$9.3 \%$
d. Nowhere
b. Panama
$6.98 \%$
e. Atlantic City
$37.21 \%$
c. Las Vegas
$18.60 \%$
f. Curacao
6.988
c.
g. Bahamas, Las Vegas \& Panama
2.338
h. Aruba, Las Vegas \& Panama
$2.33 \%$
i. Las Vegas \& Panama
$2.33 \%$
j. Aruba \& Las Vegas
$4.62 \%$
k. Aruba \& Atlantic City
2.338
1. Bahamas, Las Vegas, Aruba \& Panama
2.338
m. Bahamas \& Panama
2.338 
10. What would make your stay in Miami more pleasurable?
a. Gambling
13.958
b. Less crime
11.638
d. Faster airports
2.338
c. Better hotels
$2.33 \%$
e. More activities
$4.65 \%$
f. Nothing
$65.11 \%$

1. What nationality are you?

COLOMBIAN

2. What is the main purpose of your stay in Miami?
a. Pleasure
$55.17 \%$
c. Shopping
b. Business
$34.48 \%$
d. All of the above $\overline{6.98}$

Fin

3

3. What is the average length of your stay in Miami?
a. 2 days
10.348
d. 8-14 days
20.698
b. 3-4 days
20.698
e. More than 14 days
$20.69 \%$
c. 5-7 days
27.598

4. Is your income bracket...
a. Low (under $\$ 20,000$ per year)
$20.69 \%$
b. Medium $(\$ 20,001$ to $\$ 40,000$ per year $)$
$51.72 \%$
c. High $(\$ 40,001$ and above per year)
27.598

5. Would you favor the legalization of casinos in Miami?
a. Yes
$\frac{48.28 \%}{48.28 \%}$
b. NO
$48.28 \%$
c. Indifferent
$3.44 \%$ 
6. If casinos were legalized, would you come to Miami more often?

If yes, how many more times?

If no, would this stop you,from returning

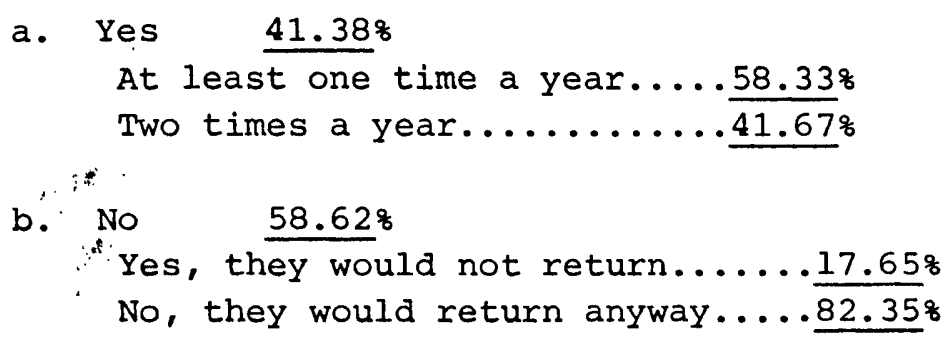

7. How much would you usualiy spend in your visits to Miami, besides that money spent on airfare?
a. Under $\$ 500.00$
27.598
b. $\$ 501.00$ to $\$ 1,000.00$
13.798
c. More than $\$ 1,000.00$
$\underline{58.62 \%}$

8. How much would you spend on gambling if it were available?
a. About $\$ 100.00$
$\underline{6.9} \%$
b. About $\$ 200.00$
10.348
c. About $\$ 300.00$
$13.79 \%$
d. About $\$ 400.00$ 3.45\%
d. About $\$ 400.00$ 3.45\%
e. About $\$ 500.00$
f. More than $\$ 1,000.00, \frac{6.9}{10.34 \%}$
g. Nothing
g. Nothing

9. Where have you been to gamble in the past?
a. Las Vegas
b. The Bahamas \& Aruba
c. Aruba \& Las Vegas
d. The Bahamas \& Panama
e. Aruba, Las Vegas \& Atlantic City

$\frac{10.33 \%}{\frac{3.45}{3.45} \%}$
Atlantic City Las Vegas $\frac{3.9 \%}{3.45 \%}$
$\frac{65.45 \%}{65 \%}$
f. The Bahamas, Aruba \& Las Vegas
$\ddot{g} \cdot$ Nowhere

10. What would make your stay in Miami more pleasurable?
a. "Gambling
13.798
e. Lower prices
3.458
b: Less crime
13.798
f. Cleaner beaches
$3.45 \%$
c. Better hotels
$3.45 \%$
g. Nothing
$58.62 \%$
d. Better food
$3.45 \%$ 
1. What nationality are you?

MEXICAN

2. What is the main purpose of your visit?
a. Pleasure
$66.66 \%$
c. Shopping
$6.678^{\prime}$
b. Business $\overline{20.0} \%$
d. All of the above
$6.67 \%$

3. What is the average length of your stay in Miami?
a. 2 days
$6.66 \%$
d. 8-14 days
$\frac{26.67 \%}{20.0}$
b. 3-4 days
20.08
c. 5-7 days
26.678
e. More than 14 days

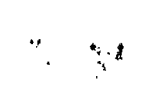


7. How much do you usually spend in your visits to Miami, besides that money spent on airfare?
a. Under $\$ 500.00$
$20.0 \%$
b. $\$ 501.00$ to $\$ 1,000.00$
$33.33 \%$
c. More than $\$ 1,000.00$
$46.67 \%$

8. How much would you spend on gambling if it were available?
a. About $\$ 100.00$
$0.0 \%$
d. About $\$ 500.00$
$33.32 \%$
b. About $\$ 200.00 \quad 26.67 \%$
e. More than $\$ 1,000.00$
$6.67 \%$
c. About $\$ 300.00$
$6.67 \%$
f. Nothing
$26.67 \%$

9. Where have you been to gamble in the past?
a. Las Vegas
$33.33 \%$
c. Las Vegas \& Panama
$6.67 \%$
b. Panama
$26.67 \%$
d. Nowhere
33.338

10. What would make your stay in Miami more pleasurable?
a. Gambling
$33.33 \%$
b. Better food
$13.33 \%$
c. Nothing
$53.34 \%$

3 


\section{4 \\ APPENDIX C}

The sample size of 94 is necessary to be 95 percent confident that the population parameter is within \pm 10 percentage points of the sample proportion.

1. \pm 10 is the desired interval range within which population proportion is expected

2. $1.96 \delta_{p}=.95$ confidence level for estimating interval within which to expect the population proportion.

3. $\sigma_{p}$ is 0.051 standard error of the proportion (.10/1.96)

4. $\mathrm{Pa}$ is a measure of sample dispersion used here as an estimate of population dispersion.

5. $\sigma_{p}=\sqrt{\frac{p \cdot q}{n-1}}=0.051=\sqrt{\frac{.6 \times \cdot 4}{n-1}}=\sqrt{\frac{.24}{n-1}}$
$n=93$

6. Sample size $=93$. 